\author{
Ilona Tomczyk-Wydrych ${ }^{\mathrm{a}}$, Anna Rabajczyk ${ }^{\mathrm{b}}{ }^{*}$ \\ a) The State Water Holding Polish Waters / Państwowe Gospodarstwo Wodne Wody Polskie \\ b) Scientific and Research Centre for Fire Protection - National Research Institute / Centrum Naukowo-Badawcze Ochrony \\ Przeciwpożarowej im. Józefa Tuliszkowskiego - Państwowy Instytut Badawczy \\ *Corresponding author / Autor korespondencyjny: arabajczyk@cnbop.pl
}

\title{
Metal Nanoparticles in Surface Waters - a Risk to Aquatic Organisms
}

\section{Nanocząstki metali w wodach powierzchniowych - zagrożenie dla organizmów wodnych}

\begin{abstract}
Purpose: The aim of this paper is to provide information on the risks posed by metal nanoparticles released into surface waters. Introduction: Currently, the use of nanoparticles of metal and metal oxides (NPMOs) is extremely popular in various industries, and in medicine and households. Nanoparticles and nanocompounds have become significant contributors to technological progress due to their physicochemical properties such as the melting point, electrical and thermal conductivity, catalytic activity, light absorption and scattering, as well as biocompatible and bactericidal properties. These functions cause their increased performance compared to their macro counterparts. However, it should be noted that the properties of nanocomponents can create new risks to the environment and consumers.

Based on existing literature, a conclusion can be drawn that metal nanoparticles are a potential threat to plant and animal organisms, and humans. It is, therefore, necessary to intensify efforts to understand the mobility, reactivity and durability of nanocomponents in various environmental components, especially in the aquatic environment, and their toxicity to organisms.

Methodology: This paper is a literature review.

Conclusions: The increasing use of nanosubstances, in both commercial and industrial products, has caused an increasing concentration and diversity of these substances in aquatic ecosystems. Based on the analysis of literature reports, it can be concluded that the size of nanoparticles, their structure and arrangement, as well as surface properties, are subject to constant changes in the environment as a result of their interactions with other components, and of the balances shaped by a variety of geochemical and biological factors.

Numerous studies conducted in recent years in the field of nanoecotoxicology have demonstrated the existence of a risk to aquatic organisms, which could lead to their impaired development and even death. Unfortunately, the lack of a standard technique for assessing the toxicity of nanoparticles in various biological systems, such as the reproductive, respiratory, nervous and gastrointestinal systems, and the developmental stages of aquatic organisms, makes it impossible to conduct such studies in a standardised fashion.

Reports of the toxicity of metal and metal oxide nanoparticles in relation to various forms of living organisms warrant in-depth investigations into how these particles function in aqueous solutions and interact with standard substances.

Keywords: metal nanoparticles, emission, surface waters, living organisms

Type of article: review article
\end{abstract}

Received: 05.11.2019; Reviewed: 01.01.2020; Accepted: 09.01.2020;

Authors' ORCID IDs: I. Tomczyk-Wydrych - 0000-0002-1278-2615; A. Rabajczyk - 0000-0003-4476-8428;

The authors contributed the equally to this article;

Please cite as: SFT Vol. 54 Issue 2, 2019, pp. 70-88, https://doi.org/10.12845/sft.54.2.2019.5;

This is an open access article under the CC BY-SA 4.0 license (https://creativecommons.org/licenses/by-sa/4.0/).

\section{ABSTRAKT}

Cel: Celem artykułu jest przedstawienie informacji na temat zagrożeń, jakie stanowią nanocząstki metali wprowadzane do wód powierzchniowych. Wprowadzenie: Obecnie wykorzystanie nanocząstek metali i tlenków metali (NPMOs) cieszy się ogromną popularnością w różnych gałęziach przemysłu, medycynie i gospodarstwach domowych. Nanocząstki i nanozwiązki zyskały na znaczeniu w postępie technologicznym ze względu na swoje właściwości fizykochemiczne takie jak temperatura topnienia, przewodność elektryczna i cieplna, aktywność katalityczna, absorpcja i rozpraszanie światła oraz swoje biokompatybilne i bakteriobójcze własności. Cechy te powodują ich zwiększoną wydajność w stosunku do ich odpowiedników w skali makro. Należy jednak pamiętać, że właściwości, jakie posiadają nanozwiązki, mogą generować nowe ryzyko dla środowiska naturalnego oraz konsumentów. 
Analizując dotychczasową literaturę należy stwierdzić, że nanocząstki metali stanowią potencjalne zagrożenia dla organizmów roślinnych i zwierzęcych, w tym także człowieka. Konieczna jest zatem intensyfikacja prac, które pozwolą na zrozumienie mobilności, reaktywności i trwałości nanozwiązków w różnych komponentach środowiska, zwłaszcza w środowisku wodnym, oraz toksyczności w stosunku do organizmów. Metodologia: Artykuł został opracowany na podstawie przeglądu literatury z zakresu poruszanej tematyki.

Wnioski: Rosnące wykorzystanie nanosubstancji, zarówno w produktach komercyjnych, jak i przemysłowych, determinuje coraz większe stężenie i różnorodność tych substancji w ekosystemach wodnych. Na podstawie analizy doniesień literaturowych należy stwierdzić, że wielkość nanocząstek, ich budowa i układ oraz właściwości powierzchni podlegają ciągłym zmianom w środowisku w wyniku interakcji z innymi składnikami i równowag kształtowanych przez różnorodne czynniki bio- i geochemiczne.

Liczne badania przeprowadzone w ciągu ostatnich lat w dziedzinie nanoekotoksykologii wskazują na zagrożenie w stosunku do organizmów wodnych prowadzące do upośledzenia w rozwoju a nawet śmierci organizmów. Niestety, brak standardowej techniki oceny toksyczności nanocząstek w różnych układach biologicznych, takich jak układ rozrodczy, oddechowy, nerwowy, żołądkowo-jelitowy i stadia rozwojowe organizmów wodnych, powoduje brak możliwości standardowego prowadzenia takich badań.

Doniesienia o toksyczności NPMOs w odniesieniu do różnych form organizmów żywych powodują, że niezbędna jest wiedza w zakresie ich funkcjonowania w roztworach wodnych oraz interakcji z podstawowymi substancjami.

Słowa kluczowe: nanocząstki metali, emisja, wody powierzchniowe, organizmy żywe

Typ artykułu: artykuł przeglądowy

Przyjęty: 05.11.2019; Zrecenzowany: 01.01.2020; Zatwierdzony: 09.01.2020;

Identyfikatory ORCID autorów: I. Tomczyk-Wydrych - 0000-0002-1278-2615; A. Rabajczyk - 0000-0003-4476-8428;

Autorzy wnieśli równy wkład merytoryczny w powstanie artykułu;

Proszę cytować: SFT Vol. 54 Issue 2, 2019, pp. 70-88, https://doi.org/10.12845/sft.54.2.2019.5;

Artykuł udostępniany na licencji CC BY-SA 4.0 (https://creativecommons.org/licenses/by-sa/4.0/).

\section{Introduction}

The term nanotechnology encompasses the production and use of objects with at least one dimension in the range of 1-100 nm. Currently, it is a leading field of science, combining physics, chemistry, biology, medicine, IT and engineering. Nanotechnology plays an important role in the material- and energy-saving development of innovative high-performance products. Due to their constitution and size, heavy-metal based nanosubstances often exhibit new and significant biological, chemical and physical properties otherwise unattainable in macro- and microscopic structures. The large specific surface area, superparamagnetic properties, superior absorptivity, diverse crystalline structures and types of metal-oxide bonds make nanoparticles attractive materials offering a broad spectrum of applications in many areas of everyday life, as well as in the cosmetic, food and chemical industries, in medicine, optics and the energy industry, and in environmental protection and engineering.

Despite the many multifaceted benefits brought by the development of nanotechnology, it is important to realise that this development can also lead to new types of waste containing as-yet unregulated nanoparticles. New nano-based products, processes and materials entail the risk of associated emissions during production, application and deposition [1].

Given that the production of nanosubstances has been on the rise in recent years, it is reasonable to expect growing amounts of nanowaste. Mass consumption generates large amounts of waste, causing an increased presence of nanoparticles in wastewater and on landfills [2]. Hence, tracing nanoparticles within the biogeochemical cycle, including especially metal and metal oxide nanoparticles, which have their macroscale counterparts, is a difficult task which requires in-depth studies at various stages of the product life cycle, from the concept,

\section{Wprowadzenie}

Nanotechnologia jest terminem obejmującym produkcję oraz użytkowanie obiektów, których przynajmniej jeden wymiar zawiera się w przedziale od 1 do $100 \mathrm{~nm}$. Obecnie jest jedną z wiodących dziedzin nauki, która łączy wiedzę z obszaru fizyki, chemii, biologii, medycyny, informatyki i inżynierii. Odgrywa ważną rolę w rozwoju innowacyjnych produktów o zwiększonej wydajności, przy jednoczesnym zmniejszeniu zużycia surowców i energii. Nanosubstancje oparte na skonsolidowanych z nimi metalach ciężkich, ze względu na budowę i rozmiary, często wykazują nowe istotne właściwości biologiczne, chemiczne oraz fizyczne, niemożliwe do osiągnięcia na poziomie makro-i mikroskopowych struktur. Duża powierzchnia właściwa, właściwości superparamagnetyczne, doskonała zdolność sorpcyjna, różnorodność struktury kryształów i charakter wiązań metal-tlen powodują, że nanocząstki są atrakcyjnymi materiałami o szerokim spektrum zastosowań w wielu dziedzinach życia codziennego oraz przemysłach kosmetycznym, spożywczym, chemicznym, a także w medycynie, optyce, energetyce oraz ochronie i inżynierii środowiska.

Rozwój nanotechnologii niesie ze sobą wiele korzyści w różnych sferach życia codziennego. Należy jednak podkreślić, że równocześnie może generować nowy typ odpadów, zawierających cząstki nanometryczne, wobec których nie istnieją odpowiednie regulacje prawne. Nowe produkty, procesy i materiały bazujące na substancjach "nano" wiążą się z ryzykiem emisji tych związków podczas produkcji, stosowania i depozycji [1].

Biorąc pod uwagę, że produkcja nanosubstancji w ostatnich latach dynamicznie wzrasta, można spodziewać się w konsekwencji również wzrostu ilości nanoodpadów. Zwiększeniu obecności nanocząstek w ściekach i na składowiskach odpadów sprzyja również masowa konsumpcja, generująca dużą ilość odpadów [2]. Dlatego też śledzenie losu nanocząstek w cyklu biogeochemicznym, zwłaszcza metali i tlenków metali, mających swoje odpo- 
to research and development, to production and distribution, to utilisation and, finally, to disposal or recycling.

Based on the life cycle assessment, attempts were made to identify potential sources of emissions and environmental risks associated with the use of nanoparticles [3-5] (Figure 1).

It is estimated that, among other products, the global market manufactures 1,000 tonnes of personal care products containing zinc-oxide nanoparticles (ZnO NPs). The widespread use of sunscreens containing ZnO NPs leads to a substantial release of these particles into the aquatic environment, especially during summer. Scientists have estimated that at least $25 \%$ of the sunscreen applied on skin is washed off when bathing and swimming. Consequently, about 250 tonnes of $\mathrm{ZnO}$ NPs are released each year into the aquatic environment during summer [6-7]. What is more, the use of $\mathrm{ZnO} N P s$ in rubber products raised questions as to the associated environmental impact. Indeed, at the last stage of the life cycle, this compound is released to the lithosphere due to wear and tear of rubber-based materials [8]. This, in turn, might cause ZnO NPs to penetrate into the aquatic environment at further migration stages due to dry or wet deposition.

Once present in industrial and municipal wastewater, these compounds migrate further to surface waters and soil, eventually making their way to the food chain. Exploring the properties and behaviour of these substances in aqueous solutions has, therefore, become a priority for human security and environmental protection [1], [9-12].

The migrations and behaviour of these pollutants can pose environmental and human risks [10], 13-15] This has provoked discussions about the safety of, and potential risks associated with, nanotechnology. A strong emphasis has been placed on determining the toxicity of nanostructures to various groups of organisms, including perennials, wheat, bacteria, protozoa, macrophytes, earthworms, fish, mice and rats [16-25]. It also appears extremely important to determine the characteristics and stability of nanoparticles in order to understand how they function in aqueous solutions and interact with standard substances in the environment [1], 9-12].

\section{Sources of nanoparticle emissions}

Metal nanoparticles occur naturally irrespective of human activity. They are found in the hydrosphere, atmosphere, lithosphere and biosphere. This is caused by natural processes such as photochemical reactions, volcano eruptions, forest fires, erosion, sandstorms, the last one being arguably the biggest source of metal nanoparticle emissions into the environment. As a result of air processes, NPMOs can undergo transformation, or depose in their primary form on soil, water and plant surfaces, from which they can migrate further into the environment. Other natural sources of nanoparticles in the environment include subsoil, bottom sediments and soil. In the case of water bodies, nanostructures can also be formed by processes such as precipitation, temperature change and evaporation [26-27]. wiedniki w skali makro, nie jest łatwe i wymaga wnikliwych badań na różnym etapie cyklu życia produktu, począwszy od momentu powstania koncepcji, poprzez badania i rozwój, produkcję, dystrybucję i wykorzystanie aż do usunięcia lub recyklingu.

Bazując na analizię cyklu życia nanoproduktu (LCA, ang. Life Cycle Assessment) podjęto próby określenia potencjalnych źródeł emisji oraz zagrożenia dla środowiska wynikające $z$ wykorzystania nanocząstek [3-5] (ryc. 1).

Ocenia się, że rynek globalny produkuje m.in. 1000 ton produktów pielęgnacyjnych zawierających ZnO NPs (ang. zinc oxide nanoparticles). Korzystanie z filtrów przeciwsłonecznych zawierających ZnO NPs powoduje, że są one w dużych ilościach wprowadzane do środowiska wodnego, zwłaszcza w okresie letniego wypoczynku. Naukowcy obliczyli, że co najmniej $25 \%$ kremu do opalania stosowanego na skórę zmywa się podczas kąpieli i pływania. Oznacza to, że około 250 ton ZnO NPs jest potencjalnie aplikowane co roku do środowiska wodnego podczas kąpieli w okresie lata [6-7]. Z kolei wykorzystanie nanocząstek tlenku cynku w produktach gumowych wywołało pytania dotyczące jego oddziaływania na środowisko, ponieważ związek ten w ostatnim etapie swojego cyklu życia emitowany jest do litosfery w wyniku ścierania gumy [8]. To z kolei może się przyczynić do wprowadzenia ZnO NPs do środowiska wodnego na dalszych etapach migracji, na skutek suchej bądź mokrej depozycji.

Obecne w ściekach przemysłowych oraz miejskich związki migrują dalej do wód powierzchniowych i gleb, a w konsekwencji wprowadzane są do łańcucha pokarmowego. Dlatego też poznanie właściwości i zachowania nanocząstek metali w roztworach wodnych staje się priorytetem w dziedzinie bezpieczeństwa, ochrony środowiska i człowieka [1], [9-12].

Losy i zachowanie się tych zanieczyszczeń mogą stanowić potencjalne zagrożenie dla środowiska oraz człowieka [10], [13-15]. Dlatego też nanotechnologia jest przedmiotem dyskusji w kontekście bezpieczeństwa i ryzyka. Duży nacisk położony jest na określenie toksyczności nanostruktur w odniesieniu do różnych grup organizmów, w tym bylin, pszenicy, bakterii, pierwotniaków, makrofitów, dżdżownic, ryb, myszy, szczurów [16-25]. Określenie cech i stabilności nanocząstek jest bardzo istotne, gdyż pozwala także zrozumieć ich funkcjonowanie w roztworach wodnych oraz w interakcji z podstawowymi substancjami obecnymi w środowisku [1], [9-12].

\section{Źródła emisji nanocząstek}

Niezależnie od ludzkiej działalności naturalnie występujące nanocząstki metali są formowane i obecne w hydrosferze, atmosferze, litosferze i biosferze. Naturalnymi procesami przyczyniającymi się do emisji nanocząstek są reakcje fotochemiczne, erupcje wulkanów, pożary lasów, erozje i burze pisakowe. Burze pyłowe są uważane ze największe źródło nanocząstek metali w środowisku. W wyniku procesów zachodzących w powietrzu NPMOs mogą ulec przekształceniu bądź w postaci pierwotnej ulec depozycji na powierzchni gleby, wody, roślin, stanowiących o dalszej migracji w środowisku. Także podłoże geologiczne, osady denne, gleba stanowią naturalne źródło nanocząstek w środowisku. W przypadku zbiorników wodnych nanostruktury mogą tworzyć się dodatkowo 
The widespread use of metal nanoparticles in everyday products and many industries, including in agriculture (Table 1), has led to an ever-growing number of sources of these nanostructures. w wyniku takich procesów jak wytrącanie, zmiana temperatury i odparowanie [26-27].

Powszechne zastosowanie nanocząstek metali w produktach codziennego użytku oraz w wielu gospodarkach przemysłu, także rolnictwie (tab. 1), powoduje, że źródeł emisji tych nanostruktur jest coraz więcej.

Table 1. Examples of nanoparticle applications in various industries and households

Tabela 1. Przykłady zastosowań nanocząstek w różnych gałęziach przemysłu i gospodarstwach domowych

\begin{tabular}{|c|c|c|c|}
\hline Industry / Przemysł & Nanoparticles / NPs & Application / Zastosowanie & $\begin{array}{l}\text { Literature / } \\
\text { Literatura }\end{array}$ \\
\hline \multirow{10}{*}{$\begin{array}{l}\text { Medicine and pharmacy } \\
\text { / Medycyna } \\
\text { i farmacja }\end{array}$} & \multirow[t]{2}{*}{$\mathrm{Ag}$} & $\begin{array}{l}\text { antibacterial, antiviral, antifungal agents; drug carriers, wound dressings, } \\
\text { cardiovascular implants, dental materials, for coating contact lenses, } \\
\text { diagnosis of cancer treatment / środki przeciwbakteryjne, przeciwwirusowe, } \\
\text { przeciwgrzybiczne, nośniki leków, opatrunki na rany, implanty sercowo-na- } \\
\text { czyniowe, materiały dentystyczne, do powlekania soczewek kontaktowych, } \\
\text { diagnostyka leczenia nowotworów / }\end{array}$ & [28] \\
\hline & & $\begin{array}{l}\text { contrast agent for computed tomography (CT) / środek kontrastowy do } \\
\text { tomografii komputerowej }\end{array}$ & [29] \\
\hline & $\mathrm{Au}$ & biosensors, drug carriers / biosensory, nośniki leków & [30] \\
\hline & \multirow[b]{2}{*}{$\mathrm{Cu}$} & bactericidal coatings / powłoki bakteriobójcze & [31] \\
\hline & & $\begin{array}{l}\text { germicide, antimicrobial agent in the treatment of infectious diseases / } \\
\text { środek bakteriobójczy, środek do zwalczania drobnoustrojów w leczeniu } \\
\text { chorób zakaźnych }\end{array}$ & [32] \\
\hline & \multirow[b]{2}{*}{$\mathrm{ZnO}$} & antibacterial toothpastes / antybakteryjne pasty do zębów & [28] \\
\hline & & $\begin{array}{l}\text { creams, lotions as a material that absorbs UV radiation, used for cancer the- } \\
\text { rapy (nanocapsules used to transport drugs in the body), dental materials as } \\
\text { a fraction of a dental composite, coatings of medical materials (antibacterial } \\
\text { properties, effectively reducing the possibility of infection by bacteria, e.g. } \\
\text { Escherichia coli, Staphylococcus aureus and Pseudomonas aeruginosa / kremy, } \\
\text { balsamy jako materiał pochłaniający promieniowanie UV, wykorzystywany } \\
\text { do terapii nowotworowej (nanokapsuły wykorzystywane do transportu leków } \\
\text { w organizmie), materiały dentystyczne jako frakcja kompozytu stomatolo- } \\
\text { gicznego, powłoki materiałów medycznych (właściwości antybakteryjne, } \\
\text { skutecznie redukujące możliwość zakażeń przez bakterie np. Escherichia coli, } \\
\text { Staphylococcus aureus oraz Pseudomonas aeruginosa }\end{array}$ & [33-36] \\
\hline & \multirow[t]{2}{*}{$\mathrm{Fe}_{2} \mathrm{O}_{3}$} & $\begin{array}{c}\text { bactericides, drug carriers, magnetic hydrogels, MRI contrast media / } \\
\text { środki bakteriobójcze, nośniki leków, hydrożele o właściwościach } \\
\text { magnetycznych, środki kontrastowe do MRI }\end{array}$ & [37] \\
\hline & & for labeling stem cells / do znakowania komórek macierzystych & [29] \\
\hline & $\mathrm{TiO}_{2}$ & $\begin{array}{l}\text { addition to pharmaceutical products (e.g. anti-cancer drugs) / dodatek do } \\
\text { produktów farmaceutycznych (np. leków przeciwnowotworowych) }\end{array}$ & [38] \\
\hline \multirow{5}{*}{$\begin{array}{l}\text { Cosmetology / } \\
\text { Kosmetologia }\end{array}$} & $\mathrm{Ag}$ & $\begin{array}{c}\text { preservative e.g. shampoos, toothpastes, face creams, soaps, moisturizing } \\
\text { wipes, deodorants, lipsticks and lip balms / środek konserwujący np. szam- } \\
\text { ponów, pasty do zębów, kremy do twarzy, mydła, chusteczki nawilżające, } \\
\text { dezodoranty, szminki i balsamy do ust }\end{array}$ & [39] \\
\hline & $\mathrm{Au}$ & moisturizing oils, body lotions / olejki nawilżające, balsamy do ciała & [1] \\
\hline & $\mathrm{ZnO}$ & $\begin{array}{l}\text { creams with UV filters, lipsticks, lip balms / kremy z filtrami UV, szminki, } \\
\text { balsamy do ust }\end{array}$ & {$[41-42]$} \\
\hline & $\mathrm{TiO}_{2}$ & sunscreens/filtry przeciwsłoneczne & [40-42] \\
\hline & $\mathrm{Fe}_{2} \mathrm{O}_{3}$ & $\begin{array}{c}\text { sunscreen, face cosmetics (lipsticks, eye shadows, mascaras, powders), nail } \\
\text { polishes / kremy z filtrem, kosmetyki do twarzy (szminki, cienie do powiek, } \\
\text { tusze do rzęs, pudry), lakiery do paznokci }\end{array}$ & [37] \\
\hline
\end{tabular}




\begin{tabular}{|c|c|c|c|}
\hline \multirow{5}{*}{$\begin{array}{l}\text { Food industry / } \\
\text { Przemysł spożywczy }\end{array}$} & $\mathrm{Au}$ & food packaging machine coatings / powłoki maszyn do pakowania żywności & [43] \\
\hline & $\mathrm{Ag}$ & packaging films, refrigerators / folie opakowaniowe, lodówki & [44] \\
\hline & $\mathrm{TiO}_{2}$ & food additive / dodatek do żywności & [45] \\
\hline & $\mathrm{Fe}_{2} \mathrm{O}_{3}$ & $\begin{array}{l}\text { packaging additive, germicide, addition to food dyes / dodatek do opakowań, } \\
\text { środek bakteriobójczy, dodatek do barwników spożywczych }\end{array}$ & [37] \\
\hline & $\mathrm{ZnO}$ & $\begin{array}{l}\text { packaging from polymer nanocomposites, in which the role of the filler is } \\
\text { played by ZnO NPs / opakowania z nanokompozytów polimerowych, } \\
\text { w których role napełniacza pełnią n-ZnO }\end{array}$ & [46] \\
\hline \multirow{5}{*}{$\begin{array}{l}\text { Textile industry / } \\
\text { Przemysł tekstylny }\end{array}$} & $\mathrm{Ag}, \mathrm{Au}, \mathrm{Cu}, \mathrm{SiO}_{2}$ & $\begin{array}{l}\text { clothing, underwear, bedding, sheets, tablecloths, towels, mattresses / } \\
\text { odzież, bielizna, pościel, prześcieradła, obrusy, ręczniki, materace }\end{array}$ & [1], [47] \\
\hline & $\mathrm{Ag}, \mathrm{Cu}, \mathrm{Zn}$ & antimicrobial textiles / tkaniny zwalczające drobnoustroje & [47] \\
\hline & $\mathrm{Au} / \mathrm{TiO}_{2}$ & \multirow{2}{*}{$\begin{array}{l}\text { fiber coatings (catalytic properties) / tworzą powłokę włókien } \\
\text { (właściwości katalityczne) }\end{array}$} & [48] \\
\hline & $\mathrm{Cu}, \mathrm{CuO}$ & & [49] \\
\hline & $\mathrm{ZnO}$ & $\begin{array}{l}\text { highly durable, effective fabrics for absorbing and scattering UV radiation / } \\
\text { wysoko wytrzymałe, skuteczne w pochłanianiu i rozpraszaniu promieniowa- } \\
\text { nia UV tkaniny }\end{array}$ & [50] \\
\hline \multirow{5}{*}{$\begin{array}{l}\text { Environmental protection } \\
\text { and engineering / } \\
\text { Ochrona i inżynieria } \\
\text { środowiska }\end{array}$} & $\mathrm{Au}, \mathrm{Ag}, \mathrm{TiO}_{2}, \mathrm{ZnO}$ & water disinfection, water treatment / dezynfekcja wody, oczyszczanie wody & [51-53] \\
\hline & & water treatment / oczyszczanie wody & [32] \\
\hline & $\mathrm{Cu}$ & $\begin{array}{l}\text { antibacterial and antifouling agent used in water purification / środek prze- } \\
\text { ciwbakteryjny i przeciwporostowy stosowany w oczyszczaniu wody }\end{array}$ & [47] \\
\hline & $\mathrm{Fe}_{2} \mathrm{O}_{3}$ & $\begin{array}{l}\text { factor for removing metals from soil and water / adsorbent do usuwania } \\
\text { metali z gleby i wody }\end{array}$ & [54] \\
\hline & $\mathrm{ZnO}$ & $\begin{array}{l}\text { solar farm, production of solar cells with ZnO NPs / fotowoltaika, produkcja } \\
\text { ogniw słonecznych z nZnO }\end{array}$ & [55-57] \\
\hline \multirow{3}{*}{$\begin{array}{l}\text { Car industry / Przemysł } \\
\text { samochodowy }\end{array}$} & Zn-Mg-Al & biofuel catalyst / katalizator biopaliw & [58] \\
\hline & $\mathrm{Ag}, \mathrm{Cu}, \mathrm{SiO}_{2}$ & $\begin{array}{l}\text { filters, air conditioning, upholstery, cables / filtry, klimatyzacja, tapicerka, } \\
\text { kable }\end{array}$ & [37] \\
\hline & $\mathrm{Fe}_{2} \mathrm{O}_{3}$ & $\begin{array}{c}\text { paint pigments, additives for polymer coatings, self-cleaning glass coatings, } \\
\text { gas sensors / pigmenty do farb, dodatki do powłok polimerowych, powłok } \\
\text { szkieł samoczyszczących, czujniki gazu }\end{array}$ & [37] \\
\hline \multirow[b]{2}{*}{ Electronics / Elektronika } & $\begin{array}{l}\mathrm{Au}, \mathrm{ZnSe}, \mathrm{Fe}_{3} \mathrm{O}_{4} / \mathrm{Au}, / \\
\text { oxide tlenki: } \mathrm{Sn}, \mathrm{Ce}, \mathrm{Co} \\
\mathrm{Fe}, \mathrm{Ni}, \mathrm{Au}, \mathrm{Ag}, \mathrm{Cu}\end{array}$ & transistors, detectors, sensors / tranzystory, detektory, czujniki & [1] \\
\hline & $\mathrm{ZnO}$ & $\begin{array}{l}\text { optoelectronics, piezoelectrics, laser technology, light-emitting diodes, nano- } \\
\text { generators for the conversion of mechanical energy into electricity, varistors, } \\
\text { sensors for } \mathrm{CO} \text { and } \mathrm{CO}_{2}, \mathrm{H}_{2}, \mathrm{SF}_{6}, \mathrm{C}_{4} \mathrm{H}_{10}, \mathrm{C}_{2} \mathrm{H}_{5} \mathrm{OH} \text { detection / optoelektronika, } \\
\text { piezoelektryka, technologia laserowa, diody elektroluminescencyjne, nanoge- } \\
\text { neratory do konwersji energii mechanicznej w energię elektryczną, warystory, } \\
\text { czujniki do wykrywania } \mathrm{CO} \text { i } \mathrm{CO}_{2}, \mathrm{H}_{2}, \mathrm{SF}_{6}, \mathrm{C}_{4} \mathrm{H}_{10}, \mathrm{C}_{2} \mathrm{H}_{5} \mathrm{OH}\end{array}$ & [59-63] \\
\hline \multirow{4}{*}{$\begin{array}{l}\text { Construction / } \\
\text { Budownictwo }\end{array}$} & $\mathrm{Cu}, \mathrm{Mo}, \mathrm{V}$ & steel additive / dodatek do stali & \multirow{3}{*}{ [64] } \\
\hline & $\mathrm{SiO}_{2}$ & $\begin{array}{l}\text { cement additive, waterproof coatings, fireproof glass / dodatek do cementu, } \\
\text { powłoki wodoodporne, szkła ognioodporne }\end{array}$ & \\
\hline & $\mathrm{TiO}_{2}$ & $\begin{array}{l}\text { self-cleaning glass, anti-reflective coatings / szkła samoczyszczące, powłoki } \\
\text { antyrefleksyjne }\end{array}$ & \\
\hline & $\mathrm{FevO}_{3}$ & $\begin{array}{l}\text { addition to concrete, cement, ceramics, paints / dodatek do betonu, cementu, } \\
\text { ceramiki, farb }\end{array}$ & [37] \\
\hline \multirow{3}{*}{$\begin{array}{l}\text { Households / } \\
\text { Gospodarstwa domowe }\end{array}$} & $\mathrm{Ag}$ & air fresheners / odświeżacze powietrza & [65] \\
\hline & $\mathrm{Ag}, \mathrm{Au}$ & detergents / detergenty & [66] \\
\hline & $\mathrm{Ag}, \mathrm{Cu}, \mathrm{SiO}_{2}, \mathrm{TiO}_{2}, \mathrm{ZnO}$ & $\begin{array}{l}\text { rugs, upholstered furniture, curtains, anti-bacterial } \\
\text { coatings for countertops / dywany, meble tapicerowane, } \\
\text { zasłony, powłoki antybakteryjne blatów }\end{array}$ & [1] \\
\hline
\end{tabular}


Anthropogenic nanoparticles can penetrate into the environment in one of the three ways, i.e. by being released (i) during raw material manufacture; (ii) when used; and (iii) after the disposal of products containing nanoparticles. The release of nanoparticles into the environment can occur directly, including through diesel fuel and charcoal burning, welding, refining, smelting and smoking cigarettes; or indirectly, through wastewater treatment, landfilling, using fertilisers and pesticides, wear and tear of car tyres, and combustion [4-5]. In addition, they exhibit an increasingly complex structure, which influences their physicochemical and biological activity, and thereby the way they impact organisms.

Nevertheless, it should be mentioned that, according to Taylor (2002) [67], only about $10 \%$ of total atmospheric aerosols are caused by human activity, while naturally generated aerosols comprise as much as $90 \%$. However, it is worth stressing at this point that due to the ever-growing use and production of nanostructures, these proportions may have changed substantially by now. Moreover, these synthetic nanoparticles are a new kind of nanoparticles with potentially adverse impacts on the environment and human health [68]. Hence, it is necessary to identify sources of these pollutants, including those related to the production of waste and landfilling, and tracing their migration routes and the changes they undergo in the environment [2], [27], [69].

\section{Impact on aquatic organisms}

The prevalence of nanosubstances in daily use materials and the economy has made it necessary to determine the toxicity of these compounds to aquatic organisms. The toxicity of nanocompounds depends on the size of the particle, shape, area, charge, chemical properties, liquid solubility, oxidability and the physical state. According to scientists, nanoparticles interact with microorganic cells in a number of mutually supportive ways - by interacting with DNA, proteins and the cell membrane, by producing toxins, and through catalytic oxidation. Metal nanoparticles have a structure which allows them to bind with the cell membrane or freely pass through it. Given the ease with which bacteria and nanoparticles can interact, their interrelations should be investigated in more depth. Some of the metal nanoparticles bond with the amino acid cysteine, which is the building block of each enzyme. This causes the destruction of the spatial structure of proteins and the inactivation of their functions. And disrupted cellular metabolism leads to the accumulation of harmful metabolic byproducts [70].

What is more, unlike their macrocounterparts, metal and metal oxide nanoparticles cause oxidative stress [71], and may cause very high localised stresses in the cell - for instance, by producing radicals [71]. Surface adsorption is closely associated with oxidative stress in microorganisms. This involves a change in the natural reducing environment of healthy cells maintained
Nanocząstki antropogeniczne mogą przedostać się do środowiska jedną z trzech dróg:

- poprzez uwolnienie podczas produkcji surowców,

- poprzez emitowanie podczas użytkowania,

- poprzez uwolnienie po usunięciu produktów zawierających nanocząstki.

Emisja nanocząstek do środowiska może odbywać się w sposób bezpośredni m.in. poprzez spalanie oleju napędowego, węgla drzewnego, spawanie, rafinację, wytapianie, a także palenie papierosów lub pośredni w wyniku oczyszczania ścieków, składowania odpadów, wykorzystania nawozów i pestycydów, ścierania opon samochodowych oraz spalania [4-5]. Nanocząstki antropogeniczne charakteryzują się coraz bardziej skomplikowaną, złożoną strukturą, co wpływa na ich aktywność fizyko-chemiczno-biologiczną i tym samym oddziaływanie na organizmy.

Należy jednakże nadmienić, że zgodnie z doniesieniami Taylor (2002) [67] tylko około 10\% całkowitych aerozoli w atmosferze powstaje w wyniku działalności człowieka, podczas gdy naturalnie generowane stanowią aż $90 \%$. Należy jednak zaznaczyć, że ze względu na coraz większe zastosowanie i produkcję nanostruktur, stosunek ten w chwili obecnej może być zdecydowanie inny. Ponadto te syntetyczne nanocząstki są nowym gatunkiem nanocząstek, które mogą wywoływać niekorzystne skutki dla środowiska i zdrowia ludzkiego [68]. Dlatego też konieczna jest identyfikacja źródeł powstawania tego typu zanieczyszczeń, łącznie z wytwarzaniem, produkcją i składowaniem odpadów. Ważną rolę odgrywać będzie również śledzenie dróg ich migracji i przemian, jakim podlegają w środowisku [2], [27], [69].

\section{Wpływ na organizmy wodne}

Duże rozpowszechnienie nanosubstancji w materiałach codziennego użytku i gospodarce spowodowało konieczność określenia toksyczności tych związków w stosunku do organizmów wodnych. Toksyczność związków z grupy "nano” zależy od rozmiaru cząstki, kształtu, powierzchni, ładunku, właściwości chemicznych, rozpuszczalności w cieczach, zdolności utleniania oraz stanu skupienia. Według naukowców istnieje kilka wspomagających się wzajemnie sposobów interakcji nanocząstek z komórkami mikroorganizmów przez oddziaływanie z DNA, białkami, błoną komórkową oraz wytwarzanie toksyn i utlenianie katalityczne. Nanocząstki metali, dzięki swojej strukturze, mogą zostać przyłączone do błony komórkowej lub swobodnie przez nią przechodzić. Łatwość powstania interakcji między bakterią a nanocząstką stwarza potrzebę głębszej analizy tych relacji. Niektóre spośród nanocząstek metali wiążą się z cysteiną - aminokwasem stanowiącym podstawę budowy każdego enzymu. W efekcie następuje zniszczenie struktury przestrzennej białka i dezaktywacja jego funkcji. Zniszczony zostaje prawidłowy metabolizm komórki, co powoduje gromadzenie się szkodliwych produktów przemiany materii [70].

Nanocząstki metali i tlenków metali powodują także powstawanie stresu oksydacyjnego, który nie jest obserwowany w kontakcie z ich odpowiednikami w skali makro [71]. Mogą one lokalnie spowodować bardzo wysokie naprężenia w komórce, na przykład wykorzystując do tego produkcję wolnych rodników [71]. Adsorpcja 
by enzyme activity. Disruptions in this environment elicit toxicity through oxidative damage to proteins, carbohydrates, lipids and DNA. However, the most common toxic effect of NPMOs involves physical damage to the membrane, causing cell death as a result of perforation, altered membrane fluidity and disorganisation.

Yet, reactive oxygen species (ROS) are the main factor in bacterial death in some cases. This is true for nanoparticles whose cytotoxicity primarily consists in causing membrane disintegration by producing ROS [72-73]. There is research to suggest that a number of factors exist which additionally stimulate ROS production by nanoparticles such as $\mathrm{Fe}_{2} \mathrm{O}_{3}, \mathrm{ZnO}$ and $\mathrm{CuO}$. These factors include blue light radiation with a wavelength of $405 \mathrm{~nm}$, contact with transition metals, defects and a less organised structure. Metal and metal oxide nanoparticles exhibit considerable reactivity, and absorb radiation, creating electron-hole pairs. Electron-hole pairs react with solved molecular oxygen, surface hydroxyl groups and absorbed water molecules, generating radicals with the hydroxyl group $(\cdot \mathrm{OH})$ and peroxide $\left(\cdot \mathrm{O}_{2}^{-}\right)$ [72], [74- 75].

A study by Yang (2012) [76] has shown that silver nanoparticles interact with thiol groups of cellular materials, leading to vital-enzyme inactivation and the inhibition of DNA replication. The very small $(<10 \mathrm{~nm})$ Ag NPs may permeate cells directly, and condition the inactivation of cell enzymes and DNA. This creates ROS and leads to cell growth inhibition, or even cell death [76-77]. Another study, conducted by Adams et al. (2006) [78], has shown that Gram-negative bacteria are less sensitive to $\mathrm{ZnO}$ than Gram-positive bacteria [78-79].

The minimum inhibitory concentration (MIC) for the investigated strains has shown that the impact of Ag NPs on Gram-positive bacterial growth is less significant than on Gram-negative bacterial growth. Diverse effects of nanoparticles of different metal oxides with the same oxidation state, i.e. $\mathrm{ZnO}$ and $\mathrm{CuO}$, on Gram-negative (Escherichia coli, Proteus mirabilis, Pseudomonas aeruginosa) and Gram-positive (Staphylococcus aureus, Enterococcus hirae) bacteria have also been revealed [80-81], indicating that only iron oxide nanoparticles exhibit some slight antibacterial effect against Gram-positive bacteria such as Staphylococcus aureus and Enterococcus hirae [80-81]. In addition, the toxicity of $\mathrm{n}-\mathrm{Cr}_{2} \mathrm{O}_{3}$ has been corroborated by the findings of Ramesh et al. (2012) [82], who employed the disk diffusion test method to illustrate the antibacterial effects of $\mathrm{Cr}_{2} \mathrm{O}_{3}$ nanoparticles. They noticed large areas of microorganism growth inhibition, a sign of the compound's antibacterial properties. Moreover, they confirmed the relationship between the concentration and the bactericidal potential [82].

Scientists have proven that the bioavailability of nanoparticles is strongly dependent on their transformations in the environment. Oxidised, reducible and soluble compounds easily absorb into organism cells [4]. Some of the nanoparticles, such as $\mathrm{Ag}, \mathrm{ZnO}$ i CuO, release ions into the aquatic environment, which are responsible for the toxic effect [83].

Research on the impact of nanoparticles on organisms has also involved algae, invertebrates and certain fish species, including the so-called indicator species, such as Danio rerio. One study found large amounts of $\mathrm{n}$-TiO2 in fish bones, which could na powierzchni jest ściśle powiązana ze stresem oksydacyjnym u mikroorganizmów. Zjawisko to polega na zmianie naturalnego środowisko redukującego utrzymywanego w zdrowych komórkach przez aktywność enzymów. Zaburzenia w prawidłowym stanie redukcji wywołują toksyczne działanie poprzez oksydacyjne uszkodzenia białek, węglowodanów, lipidów i DNA. Jednakże najczęstsze działanie toksyczne NPMOs związane jest z fizycznym uszkodzeniem membrany, co w konsekwencji prowadzi do śmierci komórki w wyniku perforacji, zmiany płynności membrany i dezorganizacji.

Istnieją jednak przypadki, w których głównym czynnikiem wywołującym śmierć bakterii jest reaktywna forma tlenu (ROS). Właśnie cytotoksyczność nanocząstek opiera się głównie na wywoływaniu dezintegracji membran przez produkcję reaktywnych form tlenu [72-73]. Według doniesień z prowadzonych badań istnieją czynniki, które dodatkowo stymulują nanocząstki (w tym np. $\mathrm{Fe}_{2} \mathrm{O}_{3}, \mathrm{ZnO}, \mathrm{CuO}$ ) do produkcji ROS. Takimi czynnikami są m.in. napromieniowanie świattem niebieskim o długości fali $405 \mathrm{~nm}$ lub kontakt z metalami przejściowymi, jak również defekty i mniej zorganizowana struktura. Nanocząstki metali i tlenków metali wykazują dużą reaktywność, absorbują promieniowanie, co z kolei prowadzi do powstawania par elektron - dziura elektronowa. Generowane pary elektron - dziura podlegają reakcjom z rozpuszczonym tlenem cząsteczkowym, powierzchniowymi grupami hydroksylowymi i zaadsorbowanymi cząsteczkami wody z wytworzeniem wolnych rodników z grup hydroksylowej $(\cdot \mathrm{OH})$ i nadtlenku $\left(\cdot \mathrm{O}_{2}^{-}\right)$[72], [74-75].

Wyniki badań prowadzonych przez Yang (2012) [76] wykazały, że nanocząstki srebra wchodzą w interakcje z grupami tiolowymi materiałów komórkowych, konsekwencją czego jest dezaktywacja enzymów życiowych i zahamowanie replikacji DNA. Małe rozmiarowo (<10 nm) Ag NPs mogą dostać się do komórek bezpośrednio i warunkować inaktywację enzymów komórkowych i DNA. Prowadzi to do powstania ROS i doprowadza do zahamowania wzrostu, a nawet śmierci komórki [76-77]. Natomiast badania przeprowadzone przez Adams i in. (2006) [78] wykazały, że bakterie Gram-ujemne są mniej wrażliwe na obecność nanocząstek ZnO niż Gram-dodatnie [78-79].

Minimalne stężenie hamujące (MIC) wobec badanych szczepów wykazało, że również Ag NPs mają mniej znaczący wpływ na wzrost bakterii Gram-dodatnich niż na bakterie Gram-ujemne. Wykazano również zróżnicowane oddziaływania nanocząstek różnych tlenków metali na tym samym stopniu utlenienia, tj. ZnO i CuO, na bakterie Gram-ujemne (Escherichia coli, Proteus mirabilis, Pseudomonas aeruginosa) i Gram-dodatnie (Staphylococcus aureus, Enterococcus hirae) [80-81]. Uzyskane wyniki wykazały, że tylko nanocząstki tlenku żelaza wykazały nieznaczne działanie przeciwbakteryjne w stosunku do bakterii Gram-dodatnich, takich jak Staphylococcus aureus i Enterococcus hirae [80-81]. Działanie toksyczne $\mathrm{n}-\mathrm{Cr}_{2} \mathrm{O}_{3}$ potwierdzają również wyniki zaprezentowane przez Ramesha i in. [82]. Zespół autorski w celu zobrazowania antybakteryjnego działania nanocząsteczek $\mathrm{Cr}_{2} \mathrm{O}_{3}$ zastosował metodę krążkowo-dyfuzyjną. Widoczne były znaczne strefy zahamowania wzrostu mikroorganizmów, co świadczy o antybakteryjnych właściwościach tego związku. Potwierdzona została również prawidłowość odnośnie wpływu stężenia na stopień bakteriobójczości [82]. 
have been attributable to the very small sizes of molecules and their increased reactivity due to the large area of the $\mathrm{n}-\mathrm{TiO}_{2}$ particle. It was also noted that the accumulation of titanium oxide nanoparticles in fish bones had dramatically changed their thermal properties [84].

The zebrafish (Danio rerio) is a model organism widely used in nanoparticle toxicity studies. Researchers have identified several phenomena associated with nanoparticle-related toxicity, including overall toxicity (e.g. mortality, hatching rate, body length), congenital disorders (e.g. angioedema, gallbladder oedema, axial defects, nerve differentiation defects, eye development and pigmentation disorders, etc.), and behavioural changes (e.g. changes in the basal rate of swimming and the sleep-wake cycle, etc.) [85].

A study by Lacave et al. (2018) [86] involving the exposure of Danio rerio to silver nanoparticles has shown that the distribution of silver in the fish body is influenced by the form assumed by this element in water (either soluble or nanoparticle). The authors also found that dissolved silver caused short-term, and nanoparticles long-term, changes in the fish's body. What is more, X-ray microanalysis showed the presence of Ag NPs in the bronchi, liver and intestines. The authors of the study proved that the fish cleansed their bodies of Ag NPS after spending six months in clean waters, but their bronchitis induced by long-term exposure to silver nanoparticles persisted longer [86].

In their study, Griffitt et al. (2008) [87] used the zebrafish, Daphnia and algae as models of various trophic levels and feeding strategies. These organisms were exposed to silver, copper, aluminium, nickel and cobalt, in the form of both soluble nanoparticles and salts, as well as $\mathrm{TiO}_{2}$ nanoparticles. The study found that Ag NPs and Cu NPs caused toxicity in all the investigated organisms, with $\mathrm{TiO}_{2} \mathrm{NPs}$ having no toxic effect in any of the conducted tests. Sensitivity to nanoparticle toxicity varied between species, with filter invertebrates being more sensitive when exposed to nanoparticles compared to larger organisms such as the zebrafish. Cu NPs and Ag NPs were toxic for all the studied organisms. LC50 for Ag NPs was in the range of $0.04 \mathrm{mg} \cdot \mathrm{dm}^{-3}$ (Daphnia pulex) to $7.2 \mathrm{mg} \cdot \mathrm{dm}^{-3}$ (Danio rerio), while for Cu NPs it ranged from $0.06 \mathrm{mg} \cdot \mathrm{dm}^{-3}$ (Daphnia pulex) to $0.94 \mathrm{mg} \cdot \mathrm{dm}^{-3}$ (Danio rerio). Daphnia pulex was also found to be highly sensitive to Ni NPs (LC50, $\left.3.89 \mathrm{mg} \cdot \mathrm{dm}^{-3}\right)$. In Ceriodaphnia dubia, all the investigated metal nanoparticles elicited toxicity after only 48 hours. Metals in the form of nanoparticles were found to be less toxic than saline solutions. Danio rerio was the only organism exhibiting higher sensitivity to the nanoparticle forms of copper and silver than to their soluble forms [87].

A study by Lekmage et al. (2018) [88] has explored the toxicity of tyrosine capped silver nanoparticles (tyr-AgNP) to three freshwater invertebrates - Hydra vulgaris, Daphnia carinata and Paratya australiensis. Additionally, the authors of the study compared the sensitivity of these organisms to tyr-Ag NPs with their sensitivity to $\mathrm{Ag}^{+}$ions. They found that $\mathrm{Ag}^{+}$ions exhibited higher toxicity to all three studied species than that of tyr-Ag NPs. The analysis of $\mathrm{LC}_{50}$ values for both tyr-Ag NP
Naukowcy dowiedli, że biodostępność nanocząstek jest silnie zależna od ich transformacji w środowisku. Te związki, które utleniają się, redukują, rozpuszczają, łatwo wchłaniają się do komórek organizmów [4]. Niektóre z nanocząstek, takie jak Ag, ZnO i CuO, w środowisku wodnym uwalniają jony, które są odpowiedzialne za działanie toksyczne [83].

Badania w zakresie wpływu nanocząstek na organizmy prowadzono także na glonach, bezkręgowcach i gatunkach ryb, w tym rybach stosowanych jako wskaźnikowe, jak np. Danio rerio. Wyniki prowadzonych badań wykazały znaczące ilości $\mathrm{n}-\mathrm{TiO}_{2} \mathrm{w}$ ościach, co mogło być spowodowane bardzo małymi rozmiarami cząstek oraz ich zwiększoną reaktywnością wynikającą z dużego pola powierzchni cząstki n-TiO ${ }_{2}$. Zauważono również, że kumulacja nanocząstek tlenku tytanu w ościach spowodowała drastyczną zmianę ich właściwości termicznych [84].

Danio pręgowany (Danio rerio) to modelowy organizm, który jest szeroko stosowany $w$ badaniach toksykologicznych nanocząstek. Naukowcy zaobserwowali kilka zjawisk będących wynikiem toksyczności wywołanej przez nanocząstki, w tym toksyczność ogólną (np. śmiertelność, szybkość/czas wykluwania się, długość ciała), wady rozwojowe (obrzęk naczynioruchowy, obrzęk woreczka żółtkowego, wady osiowe, wady różnicowania nerwów, zaburzenia rozwoju oka i pigmentacji itp.) oraz zmiany w zachowaniu (np. zmiany szybkości pływania podstawy i cyklu odpoczynku / czuwania itp.) [85].

Wyniki prowadzonych badań przez Lacave i in. [86], dotyczące ekspozycji danio pręgowanego (Danio rerio) na nanocząstki srebra wykazały, że na rozkład srebra w organizmie ryby ma wpływ forma, którą ten pierwiastek przyjmuje w wodzie (rozpuszczalna lub nanocząstka). Jednocześnie stwierdzono, że rozpuszczone srebro powoduje krótkoterminowe zmiany w organizmie ryby, a nanocząstki - zmiany długoterminowe. Mikroanaliza rentgenowska wykazała obecność Ag NPs w skrzelach, wątrobie i jelitach. Naukowcy dowiedli, że zwierzęta oczyściły się z Ag NPs zgromadzonego w ich ciałach po spędzeniu sześciu miesięcy w czystych wodach, natomiast zapalenie skrzeli utrzymywało się dłużej po ekspozycji na nanocząstki tego metalu [86].

Griffitt i in. [87] wykorzystali do badań Danio pręgowanego, rozwielitki i glony jako modele różnych poziomów troficznych i strategii żywienia. Organizmy były narażone na srebro, miedź, glin, nikiel i kobalt - zarówno w postaci nanocząstek, jak i soli rozpuszczalnych, a także nanocząstek $\mathrm{TiO}_{2}$. Wyniki wskazały, że Ag NPs i Cu NPs powodują toksyczność we wszystkich badanych organizmach. $\mathrm{TiO}_{2} \mathrm{NPs}$ nie powodowały toksyczności w żadnym z testów. Wrażliwość na toksyczność nanocząstek różniła się między gatunkami, przy czym bezkręgowce filtrujące były bardziej podatne na ekspozycję nanozwiązków w porównaniu $z$ większymi organizmami, tj. danio pręgowanym. Cu NPs i Ag NPs były toksyczne dla wszystkich badanych organizmów. LC50 dla Ag NPs mieściło się w zakresie od $0,04 \mathrm{mg} \cdot \mathrm{dm}^{-3}$ (Daphnia pulex) do $7,2 \mathrm{mg} \cdot \mathrm{dm}^{-3}$ (Danio rerio), podczas gdy dla Cu NPs od $0,06 \mathrm{mg} \cdot \mathrm{dm}^{-3}$ (Daphnia pulex) do 0,94 $\mathrm{mg} \cdot \mathrm{dm}^{-3}$ (Danio rerio). Daphnia pulex była również bardzo wrażliwa na Ni NPs $\left(\right.$ LC50, 3,89 $\left.\mathrm{mg} \cdot \mathrm{dm}^{-3}\right)$. Wszystkie badane związki metali w postaci nanocząstek powodowały toksyczność u Ceriodaphnia dubia już po 48 godzinach. Stwierdzono, że metale występujące w postaci nanocząstek były mniej 
and $\mathrm{Ag}^{+}$ions led to the conclusion that $D$. carinata, $P$. australiensis and $H$. vulgaris, respectively, were the most sensitive species [88]. A study by Zhang et al. (2015) [89] has revealed that the lethal effect of Ag NPs on Daphnia magna decreases in the presence of natural organic matter (NOM). More specifically, NOM was found to be able to reduce silver ions to Ag NPs under natural sunlight, and thereby to mitigate the severe toxicity of AgNPs [89].

Gosteva et al. (2015) [90] concluded that the toxicity of $\mathrm{TiO}_{2} \mathrm{NPs}$ and $\mathrm{Al}_{2} \mathrm{O}_{3} \mathrm{NPs}$ to Chlorella vulgaris Beijer and Daphnia magna Straus depended on the size, concentration and form of the nanoparticles. They established that $\mathrm{TiO}_{2} \mathrm{NPs}$ averaging 5 and $90 \mathrm{~nm}$ in size and $\mathrm{Al}_{2} \mathrm{O}_{3} \mathrm{NPs}$ averagely sized 7 and $70 \mathrm{~nm}$ belonged to the category of compounds with severe toxicity to the organisms in question. Conversely, no severe toxicity was found for $\mathrm{TiO}_{2} \mathrm{NPs}$ (averaging $50 \mathrm{~nm}$ in size) and their macrocounterparts [90].

Borase et al. (2019) [91] conducted a study in which they used Moina macrocopa to explore the impact of gold nanoparticle toxicity. The 48-hour $\mathrm{LC}_{50}$ for this organism exposed to $\mathrm{Au}$ NPs was $14 \pm 0.14 \mathrm{mg} \cdot \mathrm{dm}^{-3}$. The sublethal exposure of young M. macrocopa to Au NPs ( 1.47 and $2.95 \mathrm{mg} \cdot \mathrm{dm}^{-3}$ ) reduced the activity of acetylcholinesterase and digestive enzymes (trypsin and amylase). The concentration-driven increase in the activity of antioxidative enzymes such as catalase, superoxide dismutase and glutathione S-transferase suggested oxidative stress in M. macrocopa when exposed to Au NPs [91].

It should be noted that these insights into the impact of nanoparticles on freshwater organisms are largely limited, as they were gained from short-term $(\leq 48 \mathrm{~h})$ standardised studies of toxicity, which both failed to address NP migration, and lacked an understanding of the underlying toxicity mechanisms. However, one study found that under longer exposure times $(72-96 \mathrm{~h})$ an $\mathrm{n}-\mathrm{TiO}_{2}$ suspension caused toxicity to Daphnia magna at a nominal concentration of 3.8 (72 h EC(50)) and $0.73 \mathrm{mg} \cdot \mathrm{dm}^{-3}$ (96 h EC(50)) (Table 2). The authors proposed a hypothesis that the toxicity mechanism involved the coverage of the organism surface followed by disturbances in moulting. When exposed ( $\leq 6 \mathrm{~h}$ ) to an $\mathrm{n}-\mathrm{TiO}_{2}$ solution with a concentration of $2 \mathrm{mg} \cdot \mathrm{dm}^{-3}$, newborn $D$. magna exhibited "biological surface coating" which disappeared within $36 \mathrm{~h}$, over which the first moulting of the exposed organisms was 100-percent successful. Exposure lasting up to $96 \mathrm{~h}$ led to the reformation of the surface coating, and substantially reduced the moulting rate to $10 \%$, causing the mortality rate to increase to $90 \%$. Since the large majority of aquatic organisms have the coating, this form of physical toxicity of NP MOs may have widespread adverse effects on environmental health [92].

Aruoja et al. (2015) [93] investigated the toxicity of a large body of metal oxide nanoparticles $\left(\mathrm{Al}_{2} \mathrm{O}_{3}, \mathrm{Co}_{3} \mathrm{O}_{4}, \mathrm{CuO}, \mathrm{Fe}_{3} \mathrm{O}_{4}\right.$, $\mathrm{MgO}, \mathrm{Mn}_{3} \mathrm{O}_{4}, \mathrm{Sb}_{2} \mathrm{O}_{3}, \mathrm{SiO}_{2}, \mathrm{ZnO}, \mathrm{TiO}_{2}$ and $\mathrm{WO}_{3}$ ) using such organisms as the Pseudokirchneriella subcapitata algae, three species of bacteria (Vibrio fischeri, Escherichia coli, Staphylococcus aureus) and the Tetrahymena thermophila protozoa. Their algae growth inhibition tests revealed that algae with $\mathrm{EC}_{50}$ in the range of $0.1-58 \mathrm{mg} \cdot \mathrm{dm}^{-3}$ were the most sensitive among toksyczne niż roztwory soli. Jedynie Danio rerio był bardziej wrażliwy na nanocząsteczkowe postacie miedzi i srebra niż na ich rozpuszczalne formy [87].

Lekamge i in. [88] zbadali toksyczność nanocząstek srebra pokrytych tyrozyną (tyr-AgNP) wobec trzech bezkręgowców słodkowodnych Hydra vulgaris, Daphnia carinata i Paratya australiensis. Dodatkowo wrażliwość badanych organizmów na tyr-Ag NPs porównywali z jonem $\mathrm{Ag}^{+}$. Wyniki badań wykazały, że toksyczność jonów $\mathrm{Ag}^{+}$dla wszystkich trzech badanych gatunków była wyższa niż toksyczność tyr-Ag NPs. Na podstawie otrzymanych wartości $\mathrm{LC}_{50}$ zarówno dla tyr-Ag NP, jak i jonów $\mathrm{Ag}^{+}$, stwierdzono, że najbardziej wrażliwym gatunkiem jest $D$. carinata, a w dalszej kolejności $P$. australiensis i H. vulgaris [88]. Z kolei badania Zhang i in. [89] wykazały, że śmiertelne działanie Ag NPs na Daphnia magna zmniejszało się w obecności NOM. W naturalnym świetle słonecznym NOM może redukować jony srebra do Ag NPs, a tym samym łagodzić ostrą toksyczność AgNPs [89].

Gosteva i in. [90] wywnioskowali, że toksyczności $\mathrm{TiO}_{2} \mathrm{NPs}$ i $\mathrm{Al}_{2} \mathrm{O}_{3}$ NPs na Chlorella vulgaris Beijer i Daphnia magna Straus zależy od wielkości, stężenia i formy nanocząstek. Ustalili, że $\mathrm{TiO}_{2}$ $\mathrm{NPs}$ (o średnich rozmiarach 5 oraz $90 \mathrm{~nm}$ ), $\mathrm{Al}_{2} \mathrm{O}_{3} \mathrm{NPs}$ (o średnich rozmiarach cząstek 7 oraz $70 \mathrm{~nm}$ ) należą do kategorii związków o toksyczności ostrej wobec wskazanych organizmów. Nie odnotowali natomiast żadnej toksyczności ostrej dla $\mathrm{TiO}_{2} \mathrm{NPs}$ (o średnich rozmiarach cząstek $50 \mathrm{~nm}$ ) i jego makro postaci [90].

Moina macrocopa została wykorzystana w badaniu Borase i in. [91] do analizy wpływu toksyczności nanocząstek złota. 48-godzinna wartość LC50 dla Au NPs wynosiła $14{ }^{ \pm} 0,14 \mathrm{mg} \cdot \mathrm{dm}^{-3}$ w stosunku do użytego organizmu. Narażenie subletalne dla młodocianych M. macrocopa na Au NPs $\left(1,47\right.$ i $\left.2,95 \mathrm{mg} \cdot \mathrm{dm}^{-3}\right)$ zmniejszało aktywność acetylocholinoesterazy i enzymów trawiennych, tj. trypsyny i amylazy. Zależny od stężenia wzrost aktywności enzymów przeciwutleniających, takich jak katalaza, dysmutaza ponadtlenkowa i S-transferaza glutationowa, sugerował powstanie stresu oksydacyjnego w M. macrocopa po ekspozycji na Au NPs [91].

Należy zaznaczyć, że wiedza o wpływie nanocząstek na organizmy słodkowodne jest $w$ dużej mierze ograniczona do krótkoterminowych ( $\leq 48 \mathrm{~h}$ ) standardowych badań toksyczności, którym brakuje zarówno charakterystyki losów migracji NPs, jak i zrozumienia podstawowych mechanizmów wywołujących toksyczność. Zastosowanie dłuższego czasu ekspozycji (72-96 h) wykazało, że zawiesina n- $\mathrm{TiO}_{2}$ doprowadza do toksyczności Daphnia magna przy nominalnym stężeniu 3,8 (72 h EC(50)) i 0,73 mg • dm ${ }^{-3}$ (96 h EC(50)) (tab. 2). Zgodnie z zaprezentowaną hipotezą mechanizm działania toksycznego obejmuje pokrywanie powierzchni organizmu, a następnie wprowadzenie zakłóceń w procesie linienia. Nowonarodzone $D$. magna $(\leq 6 \mathrm{~h})$ wystawione na oddziaływanie roztworu $\mathrm{n}-\mathrm{TiO}_{2}$ o stężeniu $2 \mathrm{mg} \cdot \mathrm{dm}^{-3}$ wykazały „biologiczne powłoki powierzchniowe”, które zanikały w ciągu 36 h, w czasie których pierwsze linienie zakończyło się powodzeniem u $100 \%$ odsłoniętych organizmów. Ekspozycja do $96 \mathrm{~h}$ doprowadzała do ponownego tworzenia powłoki powierzchniowej i znacznie zmniejszyła szybkość linienia do 10\%, w wyniku czego nastąpił wzrost śmiertelności do $90 \%$. Ponieważ zdecydowana większość organizmów wodnych posiada powłoki, ta forma toksyczności fizycznej NPMOs 
the organisms under study. However, the highest toxicity to all organisms except for protozoa was found for $\mathrm{CuO}$ and $\mathrm{ZnO}$ $\left(E C_{50}<1 \mathrm{mg} \cdot \mathrm{dm}^{-3}\right)$. This was probably due to the formation of toxic $\mathrm{Cu}^{2+}$ and $\mathrm{Zn}^{2+}$. Conversely, at a concentration of $100 \mathrm{mg} \cdot \mathrm{dm}^{-3}$, $\mathrm{MgO}$ nanoparticles showed no adverse effect on the studied organisms. może spowodować powszechne negatywne skutki dla zdrowia środowiskowego [92].

Table 2. Toxicity of selected metal oxide nanoparticles relative to selected metal oxide nanoparticles

Tabela 2. Toksyczność wybranych nanocząstek tlenków metali względem wybranych nanocząstek tlenków metali

\begin{tabular}{|c|c|c|c|c|c|}
\hline \multirow{2}{*}{ NPMOs } & \multirow{2}{*}{ Organism / Organizm } & \multicolumn{3}{|c|}{ Toxicity / Toksyczność } & \multirow{2}{*}{$\begin{array}{l}\text { Literature / } \\
\text { Literatura }\end{array}$} \\
\hline & & EC50 & EC20 & NOEC & \\
\hline $\mathrm{ZnO}$ & \multirow{3}{*}{$\begin{array}{c}\text { Vibrio fischeri } \\
\text { (Gram-negative luminescent bacteria / } \\
\text { Bakterie luminescencyjne Gram-ujemne) }\end{array}$} & $1.9 \pm 0.2$ & $0.9 \pm 0.4$ & $0.75(0.6)$ & \multirow{9}{*}{ [94] } \\
\hline $\mathrm{CuO}$ & & $79 \pm 27$ & $24 \pm 5$ & $16(12)$ & \\
\hline $\mathrm{TiO}_{2}$ & & $>20000$ & $>20000$ & $>20000$ & \\
\hline Zno & \multirow{3}{*}{$\begin{array}{l}\text { Daphnia magna } \\
\text { (Daphnia - protozoan / } \\
\text { rozwielitka-pierwotniak) }\end{array}$} & $3.2 \pm 1.3(2.6 \pm 1.04)$ & $2.45-1.6(2.0 \pm 1.3)$ & $0.5(0.4)$ & \\
\hline CuO & & $\begin{array}{c}3.2 \pm 1.6 \\
(2.6 \pm 1.3)\end{array}$ & $1.2 \pm 0.6(0.96 \pm 0.48)$ & $0.5(0.4)$ & \\
\hline $\mathrm{TiO}_{2}$ & & $>20000$ & $\begin{array}{l}\text { not tested / } \\
\text { nie testowany }\end{array}$ & $\begin{array}{l}\text { not tested / } \\
\text { nie testowany }\end{array}$ & \\
\hline $\mathrm{ZnO}$ & \multirow{3}{*}{$\begin{array}{l}\text { Thamnocephalus platyurus } \\
\text { (crustacean / skorupiak) }\end{array}$} & $\begin{array}{c}0.18 \pm 0.03 \\
(0.14 \pm 0.02)\end{array}$ & $\begin{array}{c}0.12 \pm 0.04 \\
(0.09 \pm 0.03)\end{array}$ & $0.03(0.02)$ & \\
\hline $\mathrm{CuO}$ & & $\begin{array}{c}2.1 \pm 0.5 \\
(1.7 \pm 0.4)\end{array}$ & $\begin{array}{l}1.65 \pm 0.64 \\
(1.32 \pm 0.51)\end{array}$ & $0.5(0.4)$ & \\
\hline $\mathrm{TiO}_{2}$ & & $>20000$ & $>20000$ & $>20000$ & \\
\hline $\mathrm{ZnO}$ & \multirow{3}{*}{$\begin{array}{l}\text { Pseudokirchneriella subcapitata } \\
\text { (microalgae / mikroalga) }\end{array}$} & 0.042 & 0.023 & 0.017 & \multirow{3}{*}{ [95] } \\
\hline CuO & & 0.710 & 0.504 & 0.421 & \\
\hline $\mathrm{TiO}_{2}$ & & 5.83 & 1.81 & 0.984 & \\
\hline $\mathrm{ZnO}$ & \multirow{4}{*}{$\begin{array}{c}\text { Vibrio fischeri } \\
\text { (Gram-negative luminescent bacteria / } \\
\text { Bakterie luminescencyjne Gram-ujemne) }\end{array}$} & 2.632 & & $<1.25$ & \multirow{4}{*}{ [96] } \\
\hline $\mathrm{TiO}_{2}$ & & $>300$ & & 300 & \\
\hline $\mathrm{MgO}$ & & 25.46 & & 7.5 & \\
\hline $\mathrm{CuO}$ & & 5.903 & & 1.56 & \\
\hline $\mathrm{CuO}$ & \multirow{2}{*}{$\begin{array}{l}\text { Tetrahymena thermophila } \\
\text { (protozoan / pierwotniak) }\end{array}$} & $97.9(80.4-138)$ & & & \multirow{2}{*}{ [97] } \\
\hline Zno & & $6.8(6.4-7.3)$ & & & \\
\hline $\mathrm{AlvO}_{3}$ & \multirow{4}{*}{$\begin{array}{l}\text { Pseudokirchneriella subcapitata, Vibrio } \\
\text { fischeri, Escherichia coli, Staphylococcus } \\
\text { aureus, Tetrahymena thermophila. }\end{array}$} & $<100$ & & & \multirow{4}{*}{ [93] } \\
\hline $\mathrm{SiO}_{2}$ & & $<100$ & & & \\
\hline $\mathrm{WO}_{3}$ & & $<100$ & & & \\
\hline $\mathrm{Sb}_{2} \mathrm{O}_{3}$ & & $<100$ & & & \\
\hline
\end{tabular}

EC - effective concentration - the concentration of the toxicant causing specific changes (effects) in the tested organisms; the determination result is provided as a concentration inhibiting $20 \%$ (EC20) or $90 \%$ (EC90) of a given physiological process; NOEC - no observed effect concentration - the largest concentration (dose) at which there is no significant increase in the incidence or severity of effects of a given substance on the tested organisms relative to controls.

EC - stężenie efektywne - stężenie toksykanta powodujące powstawanie określonych zmian (efektów) w organizmach testowych; jako wynik oznaczania podawane jest stężenie hamujące w 20\% (EC20) lub 90\% (EC90) dany proces fizjologiczny; NOEC - największe stężenie (dawka), przy którym nie występuje istotny wzrost częstości lub nasilenia skutków działania lub nasilenia skutków działania danej substancji u badanych organizmów w stosunku do kontroli. 
Tests involving Danio rerio were also conducted to investigate the toxicity of $\mathrm{NiO}$ nanoparticles. It was found that $\mathrm{n}-\mathrm{NiO}$ have low toxicity due to $\mathrm{LC}_{50}$ (30 days) being at $45.0 \mathrm{mg} \cdot \mathrm{dm}^{-3}$, and $\mathrm{LC}_{100}$ (the minimum concentration causing a 100-percent death rate) was at $100.0 \mathrm{mg} \cdot \mathrm{dm}^{-3}$, and LCO (maximum non-lethal concentration) at $6.25 \mathrm{mg} \cdot \mathrm{dm}^{-3}$ for adult specimens of the zebrafish. Long-term exposure to $\mathrm{N}-\mathrm{NiO}$ can lead to an accumulation of this nanocompound in the affected organism's tissues and to an increase in toxicity, having an adverse effect on the population of aquatic organisms and the dynamics of feeding structures in aquatic systems [98].

Particle size is one of the features taken into consideration when analysing the behaviour and properties of metal nanoparticles. It was found that a smaller particle size provides a larger area and reactivity, facilitating permeation of cells and organisms by nanoparticles, and effectively augmenting toxic effects. Lopes et al. (2014) [99] conducted a study using nanoparticles sized 30 and $80-100 \mathrm{~nm}$. They concluded that the toxicity of the nanoparticles was driven primarily by their form. Moreover, they noticed that in the case of severe toxicity, $\mathrm{ZnO}$ macroparticles exhibited a larger $\mathrm{LC}_{50}$, compared to that of $\mathrm{n}-\mathrm{ZnO}$, which was probably the consequence of zinc having both the particulate and ionic form. Indeed, within 48 hours particles larger than $200 \mathrm{~nm}$ released more ions compared to $\mathrm{n}-\mathrm{ZnO}$ of various grain sizes, this being the likely cause of the similarities in $\mathrm{LC}_{50}$ values found between the nanoparticles and the ions [99]. Toxicity is also influenced by aggregation in aqueous suspensions, to which nanoparticles are highly prone. Aggregation causes changes in physicochemical properties, making particles less available and thus less toxic [99].

One study investigated the ecotoxicity of $\mathrm{n}-\mathrm{TiO}_{2}$ sized 10 and $30 \mathrm{~nm}$, and of $\mathrm{TiO}_{2}$ sized $300 \mathrm{~nm}$, for the green algae Pseudokirchneriella subcapitata [100]. Algae growth inhibition was found for all analysed $\mathrm{n}-\mathrm{TiO}_{2}$ particles. It should be noted, however, that the presence of $\mathrm{TiO}_{2}$ nanoparticles reduced the toxicity of bioavailable cadmium, which was most likely the effect of $\mathrm{Cd}^{2+}$ sorption/complexation on the surface of titanium(II) oxide nanoparticles. However, $\mathrm{TiO}_{2}$ nanoparticles sized $30 \mathrm{~nm}$ were found to cause increased growth inhibition, which could be explained by the concentration of $\mathrm{Cd}(\mathrm{II})$ ions, suggesting a potential combination of the toxic effects of $\mathrm{TiO}_{2}$ and cadmium ions [100]. $\mathrm{TiO}_{2}$ ecotoxicity was also found for Ceriodaphnia dubia, a species of water flea in the class Branchiopoda, living in freshwater lakes, ponds and marshes in most countries in the world, and used in toxicity testing of wastewater treatment plant effluent water in the United States [101].

Freshwater Anthropoda include Daphnia similis, which are found in saline waters, alkaline ponds and fishless bodies of water, and Daphnia pulex, which live in temporary and permanent ponds and small lakes. The presence of $\mathrm{CeO}_{2}$ nanoparticles has a toxic effect on these organisms at a given concentration under 48 hours' exposure. $\mathrm{EC}_{50}$ was observed for Daphnia similis already at $0.26 \mathrm{mg} \cdot \mathrm{dm}^{-3}$, and for Daphnia pulex at $91.79 \mathrm{mg} \cdot \mathrm{dm}^{-3}$. The toxicity of $\mathrm{n}-\mathrm{CeO}_{2}$ to Daphnia similis is, therefore, 350 times larger than to Daphnia pulex [102].
Aruoja i in. [93] przebadali szeroką grupę nanocząstek tlenków metali $\left(\mathrm{Al}_{2} \mathrm{O}_{3}, \mathrm{Co}_{3} \mathrm{O}_{4}, \mathrm{CuO}, \mathrm{Fe}_{3} \mathrm{O}_{4}, \mathrm{MgO}, \mathrm{Mn}_{3} \mathrm{O}_{4}, \mathrm{Sb}_{2} \mathrm{O}_{3}, \mathrm{SiO}_{2}, \mathrm{ZnO}, \mathrm{TiO}_{2}\right.$ oraz $\mathrm{WO}_{3}$ ) pod względem toksyczności z zastosowaniem takich organizmów jak: algi Pseudokirchneriella subcapitata, trzy gatunki bakterii (Vibrio fischeri, Escherichia coli, Staphylococcus aureus) oraz pierwotniaki Tetrahymena thermophila. Uzyskane przez nich wyniki testu hamowania wzrostu glonów wykazały, że organizmy te z wartościami $\mathrm{EC}_{50}$ w zakresie od 0,1-58 mg • $\mathrm{dm}^{-3}$, są najbardziej wrażliwe spośród analizowanych organizmów. Jednakże najwyższą toksycznością względem wszystkich organizmów, z wyjątkiem pierwotniaków, charakteryzowały się $\mathrm{CuO}$ i ZnO $\left(\mathrm{EC}_{50}<1 \mathrm{mg} \cdot \mathrm{dm}-3\right)$, prawdopodobnie ze względu na powstawanie toksycznych jonów $\mathrm{Cu}^{2+} \mathrm{i} \mathrm{Zn}^{2+}$. Nanocząstki MgO natomiast nie wykazały w ogóle negatywnego wpływu na organizmy przy stężeniu poniżej $100 \mathrm{mg} \cdot \mathrm{dm}^{-3}$ [93].

Badania na Danio rerio prowadzono także w celu sprawdzenia toksyczności nanocząstek NiO. Wyniki badań wykazały, że n-NiO charakteryzują się niską toksycznością, gdyż LC ${ }_{50}$ (30 dni) wynosiła $45,0 \mathrm{mg} \cdot \mathrm{dm}^{-3}$, natomiast $\mathrm{LC}_{100}$ (minimalne stężenie powodujące $100 \%$ śmiertelności) było na poziomie $100,0 \mathrm{mg} \cdot \mathrm{dm}^{-3}$, a LC (maksymalne stężenie niepowodujące śmiertelności) wyniosło $6,25 \mathrm{mg} \cdot \mathrm{dm}^{-3} \mathrm{dla}$ dorosłych osobników danio pręgowanego. Narażenie organizmu na wieloletnie oddziaływanie n-NiO może prowadzić do akumulacji nanozwiązku w tkankach i do zwiększenia toksyczności, co może mieć negatywny wpływ na populację organizmów wodnych oraz dynamikę kształtowania struktur pokarmowych w systemach wodnych [98].

Rozmiar cząstek jest jedną z cech, na które zwraca się uwagę $w$ analizach zachowania i właściwości nanocząstek metali. Stwierdzono, że mniejszy rozmiar cząstki zapewnia większą powierzchnię i reaktywność. Umożliwia tym samym skuteczniejsze przenikanie nanocząstek do komórek i organizmów, co determinuje wyższe efekty toksyczności. Lopes i in. [99] przeprowadzili badania z zastosowaniem nanocząstek o rozmiarach 30 i 80-100 nm i stwierdzili, że toksyczność nanocząstek wynikała przede wszystkim z ich formy. Zauważyli ponadto, że w przypadku ostrej toksyczności makrocząstki ZnO wykazywały niższą wartość LC50 w porównaniu z wartościami n-ZnO, co prawdopodobnie było konsekwencją występowania cynku zarówno w postaci cząsteczkowej, jak i jonowej. W ciągu 48 godzin bowiem, cząstki o rozmiarach większych niż $200 \mathrm{~nm}$ uwolniły więcej jonów w porównaniu z n-ZnO, o różnej wielkości ziaren. Prawdopodobnie to jest przyczyną podobieństwa między wartościami LC50 stwierdzonymi między nimi a formą jonową [99]. Wpływ na toksyczność ma także agregacja w wodnych zawiesinach, której nanocząsteczki są bardzo podatne. W wyniku agregacji następuje zmiana właściwości fizykochemicznych, cząstki są mniej dostępne i tym samym mogą być mniej toksyczne [99].

Ekotoksyczność n- $\mathrm{TiO}_{2}$ o rozmiarach 10 i $30 \mathrm{~nm}$ oraz dla $\mathrm{TiO}_{2}$ o rozmiarach $300 \mathrm{~nm}$, badano w odniesieniu do słodkowodnych alg zielonych Pseudokirchneriella subcapitata [100]. Zahamowanie wzrostu glonów stwierdzono dla wszystkich analizowanych cząstek $\mathrm{n}-\mathrm{TiO}_{2}$. Należy jednak zaznaczyć, że obecność nanocząstek $\mathrm{TiO}_{2}$ zmniejszała toksyczność biodostępnego kadmu, co prawdopodobnie jest spowodowane sorpcją/kompleksowaniem jonów $\mathrm{Cd}^{2+}$ na powierzchni nanocząstek tlenku tytanu(II). Jednakże w przypadku nanocząstek $\mathrm{TiO}_{2}$ o rozmiarach $30 \mathrm{~nm}$ stwierdzono zwiększoną inhibicję wzrostu niż wynikałoby to ze stężenia jonów Cd(II), co wska- 
$\mathrm{CeO}_{2}$ nanoparticles exhibit toxic or stress-inducing effects also to:

- the Escherichia coli and Bacillus subtilis bacteria [103-104], the Anabaena CPB4337 cyanobacteria [105];

- the Pseudokirchneriella subcapitata aquatic green algae [105-107];

- the Caenorhabditis elegans vertebrae [108], the Gammarus roeseli and the Dreissena polymorpha bivalve [109], Mytilus galloprovincialis [110];

- $\quad$ and the Oncorhynchus mykiss vertebrae [111].

Benthos is an enormously important community of organisms in aquatic ecosystems. They serve important functions in aquatic processes, affecting the quality of waters and determining the presence of other organisms, especially plants. Hence, the presence of metal and metal oxide nanoparticles in water is very important, as under favourable aquatic conditions, they can undergo sedimentation and sorption on bottom sediments, thereby forming subsoil. Research has shown that the widely used $n-\mathrm{Al}_{2} \mathrm{O}_{3}$ is toxic and has a tendency to bioaccumulate in such benthos organisms as:

- the sludge worm (Tubifex tubifex) - food for invertebrates and fish;

- Hyalella Azteca - food for most aquatic amphibians;

- Lumbriculus Variegatus - largely feeding on dead organic matter; they are an excellent source of food for newt larvae;

- Corbicula Fluminea - a natural filter used for biotesting [112].

It should be added that in many cases the size distribution of commercially prepared particles deviates considerably from producer specifications. Furthermore, the use of microorganisms to create NPMOs poses additional difficulties in assessing the risk of presence of various metal and metal oxide nanoparticle structures in the aquatic environment. One example of this involves studies on the development of silver nanoparticles using Klebsiella pneumoniae, Escherichia coli, Enterobacter cloacae [113-114], as well as Pseudomonas stutzeri [115]. In normal conditions, the synthesis of $\mathrm{Au}$ and $\mathrm{Ag}$ nanoparticles is also based on organisms such as Lactobacillus [116], Klebsiella pneumonia, Escherichia coli and Enterobacter cloacae $[117,118]$. zuje na możliwość połączenia efektu toksyczności nanocząstek $\mathrm{TiO}_{2}$ oraz jonów kadmu [100]. Ekotoksyczność $\mathrm{TiO}_{2}$ stwierdzono także w stosunku Ceriodaphnia dubia, gatunku pchły wodnej w klasie skrzelonogi, żyjącej w jeziorach, stawach $\mathrm{i}$ bagnach w większości krajów oraz stosowanej w testach toksyczności oczyszczalni ścieków wody w Stanach Zjednoczonych [101].

Do słodkowodnych stawonogów zaliczane są m.in. Daphnia similis, która występuje w wodach zasolonych, alkalicznych stawach, bezrybnych zbiornikach wodnych, oraz Daphnia pulex żyjąca $w$ tymczasowych i trwałych stawach oraz małych jeziorach. Obecność nanocząstek $\mathrm{CeO}_{2}$ powoduje toksyczne działania względem tych organizmów przy stężeniu 48-godzinnej ekspozycji, przy czym $\mathrm{EC}_{50}$ dla Daphnia similis zaobserwowano już przy stężeniu $0,26 \mathrm{mg} \cdot \mathrm{dm}^{-3}$, podczas gdy dla Daphnia pulex przy stężeniu 91,79 $\mathrm{mg} \cdot \mathrm{dm}^{-3}$. Toksyczność $\mathrm{n}-\mathrm{CeO}_{2}$ względem Daphnia similis jest zatem 350 razy większa niż w stosunku do Daphnia pulex [102].

Nanocząstki $\mathrm{CeO}_{2}$ wykazują właściwości toksyczne lub wywołujące stres także względem:

- bakterii Escherichia coli i Bacillus subtilis [103-104], cyanobacteria Anabaena CPB4337 [105],

- aquatic green alga Pseudokirchneriella subcapitata [105-107],

- kręgowców Caenorhabditis elegans [108], Gammarus roeseli i małż Dreissena polymorpha [109], Mytilus galloprovincialis [110],

- kręgowców Oncorhynchus mykiss [111].

W ekosystemach wodnych ogromne znaczenie ma bentos. Organizmy te pełnią istotne role w procesach zachodzących w wodzie, kształtując tym samym jakość wód, determinując obecność innych organizmów, zwłaszcza roślinnych. Dlatego też istotne znaczenie ma zawartość nanocząstek metali i tlenków metali, które w wodach w sprzyjających warunkach mogą ulec sedymentacji, sorpcji na osadach dennych i tym samym budować podłoże. Wyniki badań wskazują, że powszechnie stosowany $\mathrm{n}-\mathrm{Al}_{2} \mathrm{O}_{3}$ wykazuje toksyczność oraz tendencje do bioakumulacji względem takich organizmów bentosowych, jak:

- rurecznik pospolity (Tubifex Tubifex) - pokarm dla bezkręgowców i ryb,

- kiełże meksykańskie (Hyalella Azteca) - pokarm dla mniejszych płazów wodnych,

- dżdżowniczka (Lumbriculus Variegatus) - większość żywi się martwą materią organiczną, stanowią doskonałe źródło pokarmu dla larw traszek,

- mięczak wodny (Corbicula Fluminea) - naturalny filtr, stosowany do biotestów [112].

Należy dodać, że w wielu przypadkach rozkład wielkości cząstek przygotowanych $w$ handlu odbiega znacząco od specyfikacji wytwórcy. Ponadto dodatkowe trudności w ocenie ryzyka obecności różnych struktur nanocząstek metali i tlenków metali w środowisku wodnym stwarza wykorzystywanie mikroorganizmów do tworzenia NPMOs, czego przykładem są badania nad tworzeniem nanocząstek srebra przez Klebsiella pneumoniae, Escherichia coli i Enterobacter cloacae [113-114] oraz za pomocą Pseudomonas stutzeri [115]. Synteza nanocząstek Au i Ag w warunkach standardowych także oparta jest na organizmach takich jak Lactobacillus [116] czy Klebsiella pneumonia, Escherichia coli i Enterobacter cloacae [117- 118]. 


\section{Summary and conclusions}

Metal nanoparticles are increasingly coming into use across various areas of everyday life (including cosmetics, medicine and pharmaceuticals, electronics and clothing). Thus, they are also becoming a major environmental pollutant (especially in wastewater). Reports on the toxicity of NPMOs to various forms of living organisms warrant investigations into how these pollutants function in aqueous solutions and interact with standard substances. However, current research has been focusing primarily on the methods of synthesising nanostructures, and on exploring their properties for potential market applications.

The literature review gives rise to a presumption that the size of nanoparticles, their constitution, distribution and surface properties are undergoing constant changes in the environment due to their interactions with other components, and as a result of the balances shaped by diverse bio- and geochemical properties. Hence, the particle size distribution may change in response to reactions such as sorption, aggregation, precipitation, solution and microorganism-driven processes. It is necessary to understand the mechanisms and kinetics of the processes occurring in the aquatic environment for metal nanoparticles, and whether and how electric potential can be created at the particle interface.

The growing use of nanosubstances in both commercial and industrial products has led to their accumulation in the aquatic ecosystem. The rapid development and large-scale production of nanocompounds over the last several decades has raised concerns about the potential risks they pose to the health of aquatic flora and fauna. Despite the extensive research on nanoecotoxicology in recent years, a standardised technique is yet to be developed for the assessment of nanoparticle toxicity in various biological systems, including the reproductive, respiratory, nervous and gastrointestinal systems, as well as the developmental stages of aquatic organisms. More research is needed in this area to help draft legislation on controlling the release of nanocompounds into the aquatic environment and their impact on aquatic organisms [119].

It should be noted at this point that the subjects of studies are not always specific to surface waters. However, since the pretreated wastewater is released into surface waters together with bacteria that are specific also to humans, it is necessary to investigate how they interact with NPMOs. The insights so gained could help to optimise wastewater treatment processes using nanotechnology and NPMOs.

\section{Podsumowanie i wnioski}

Nanocząstki metali coraz powszechniej są stosowane w różnych dziedzinach życia człowieka (m.in. kosmetyka, medycyna i farmaceutyka, elektronika, odzież). W związku z tym stanowią one coraz bardziej istotną grupę związków emitowanych do środowiska (zwłaszcza w postaci ścieków), a doniesienia o toksyczności NPMOs w odniesieniu do różnych form organizmów żywych powodują, że niezbędna jest wiedza w zakresie ich funkcjonowania w roztworach wodnych oraz interakcji z podstawowymi substancjami. Jednakże badania prowadzone w poszczególnych ośrodkach skupiają się przede wszystkim na metodach syntezy nanostruktur, analizy ich właściwości pod względem możliwości zastosowania w gospodarce.

Analiza poszczególnych doniesień literaturowych pozwala przypuszczać, że wielkość nanocząstek, ich budowa i układ oraz właściwości powierzchni podlegają ciągłym zmianom w środowisku w wyniku interakcji z innymi składnikami i równowag kształtowanych przez różnorodne czynniki bio- i geochemiczne. Rozkład wielkości cząstek może zatem ulec zmianie w odpowiedzi na zachodzące reakcje, takie jak sorpcja, agregacja, strącanie, rozpuszczanie oraz procesy uwarunkowane obecnością mikroorganizmów. Konieczne jest poznanie mechanizmów oraz kinetyki procesów zachodzących w środowisku wodnym w odniesieniu do nanocząstek metali oraz możliwości tworzenia potencjału elektrycznego na granicy faz cząsteczki.

Rosnące zastosowanie nanosubstancji - zarówno w produktach komercyjnych, jak i przemysłowych - doprowadziło do ich akumulacji w ekosystemie wodnym. Szybki rozwój i produkcja nanozwiązków na dużą skalę w ciągu ostatnich kilku dziesięcioleci wzbudziły obawy dotyczące ich potencjalnego zagrożenia dla zdrowia środowiska dla fauny i flory wodnej. Przeprowadzono już wiele badań w ciągu ostatnich lat w dziedzinie nanoekotoksykologii, jednak nie ma jeszcze żadnej standardowej techniki oceny toksyczności nanocząstek w różnych układach biologicznych, takich jak układ rozrodczy, oddechowy, nerwowy, żołądkowo-jelitowy i stadia rozwojowe organizmów wodnych. Niezbędne są badania w tym kierunku w celu opracowania przepisów do kontroli wpływu nanozwiązków na organizmy wodne i ich uwalniania do środowiska wodnego [119].

Należy także zaznaczyć, że obiekty badań nie zawsze są charakterystyczne dla wód powierzchniowych. Jednakże ze względu na emisję podczyszczonych ścieków do wód powierzchniowych wraz z bakteriami charakterystycznymi także dla człowieka, konieczna jest ich analiza pod kątem interakcji z NPMOs. Wiedza w tym zakresie może doprowadzić do optymalizacji technologicznych procesów oczyszczania ścieków w oparciu o nanotechnologię i NPMOs. 


\section{List of abbreviations / Wykaz skrótów}

$\begin{array}{ll}\text { NPs } & - \text { nanoparticles } \\ \text { NPMOs } & - \text { nanoparticles of metal and metal oxides } \\ \text { LCA } & \text { - Life Cycle Assessment } \\ \text { ROS } & \text { - reactive oxygen species } \\ \text { LD }_{50} & - \text { lethal dose } \\ \text { EC } & - \text { effective concentration } \\ \text { NOEC } & - \text { No Observed Effect Concentration }\end{array}$

\section{Literature / Literatura}

[1] Rabajczyk A., Possibilities for analysis of selected nanometals in solid environmental samples, „Desalination and Water Treatment" 2016, 57, 3, 1598-1610, https://doi.org /10.1080/19443994.2015.1030109.

[2] Kurwadkar S., Pugh K., Gupta A., Ingole S., Nanoparticles in the Environment: Occurrence, Distribution, and Risks, „Journal of Hazardous, Toxic, and Radioactive Waste" 2015, 19, 3, https://doi.org/10.1061/(ASCE) HZ.2153-5515.0000258.

[3] Feijoo S., González-García S., Moldes-Diz Y., Vazquez-Vazquez C., Feijoo G., Moreira M. T., Comparative life cycle assessment of different synthesis routes of magnetic nanoparticles, "Journal of Cleaner Production” 2017, 143, 528-538, https://doi.org/10.1016/j.jclepro.2016.12.079.

[4] Amde M., Liu J., Tan Z-Q., Bekana D., Transformation and bioavailability of metal oxide nanoparticles in aquatic and terrestrial environments. A review, „Environmental Pollution" 2017, 230, 250-267, https://doi.org/10.1016/j. envpol.2017.06.064.

[5] Bundschuh M., Filser J., Lüderwald S., McKee M. S., Metreveli G., Schaumann G. E., Schulz R., Wagner S., Nanoparticles in the environment: where do we come from, where do we go to?, "Environmental Sciences Europe" 2018, 30, 1, https://doi.org/10.1186/s12302-018-0132-6.

[6] Baker T. J., Tyler Ch. R., Galloway T. S., Impacts of metal and metal oxide nanoparticles on marine organism, „Environmental Pollution" 2014, 5, 257-271, https://doi. org/10.1016/j.envpol.2013.11.014.

[7] Zhou H., Wang X., Zhou Y., Yao H., Ahmad F., Evaluation of the toxicity of ZnO nanoparticles to Chlorella, vulgaris by use of the chiral perturbation approach, „Analytical and Bioanalytical Chemistry" 2014, 406, 3689-3695, https://doi.org/10.1007/s00216-014-7773-0.

[8.] Kołodziejczak-Radzimska A, Jesionowski T., Zinc Oxide - From Synthesis to Application: A Review, „Materials” 2014, 7, 2833-2881, https://doi.org/10.3390/ma7042833.

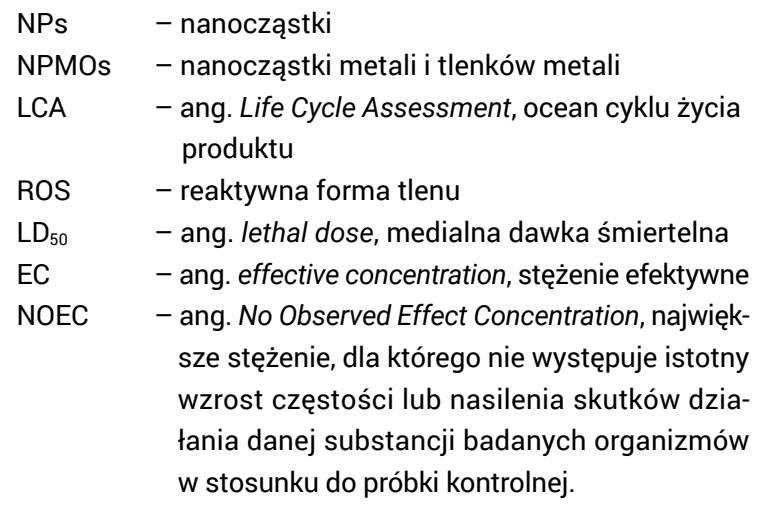

[9] Sahu S. C., Hayes A. W., Toxicity of nanomaterials found in human environment, „Toxicology Research and Application" 2017, 1, https://doi.org/10.1177/2397847317726352.

[10] Goyal P., Basniwal R. K., Toxicity of Nanoparticles and Their Impact on Environment, „Soil Biology” 2017, 48, 531-543, https://doi.org/10.1007/978-3-319-46835-8_21.

[11] Măruțescu L., Chifiriuc M. C., Postolache C., Pircalabioru G. G., Bolocan A., Nanoparticles' toxicity for humans and environment, "Nanomaterials for Drug Delivery and Therapy" 2019, 515-535, https://doi.org/10.1016/ B978-0-12-816505-8.00012-6.

[12] Han Y., Kim D., Hwang G., Lee B., Eom I., Kim P. J., Tong M., $\mathrm{Kim} \mathrm{H}$., Aggregation and dissolution of $\mathrm{ZnO}$ nanoparticles synthesized bydifferent methods: Influence of ionic strength and humic acid, "Colloids and Surfaces A: Physicochemical and Engineering Aspects" 2014, 451, 7-15, https://doi.org/10.1016/j.colsurfa.2014.03.030.

[13] Pourzahedi L., Eckelman M. J., Comparative life cycle assessment of silver nanoparticle synthesis routes, „Environmental Science: Nano" 2015, 2, 4, 361-369, https://doi. org/10.1039/C5EN00075K.

[14] Fubini B., Ghiazza M., Fenoglio I., Physico-chemical features of engineered nanoparticles relevant to their toxicity, „Nanotoxicology" 2010, 4, 347-363, https://doi.org/10.31 09/17435390.2010.509519.

[15] Sajid M., llyas M., Basheer C., Tariq M., Daud M., Baig N., Shehzad F., Impact of nanoparticles on human and environment: review of toxicity factors, exposures, control strategies, and future prospects, „Environmental Science and Pollution Research" 2014, 22, 6, 4122-4143, https://doi. org/10.1007/s11356-014-3994-1.

[16] Bourdineaud J. P., Štambuk A., Šrut M., Radić Brkanac S., Ivanković D., Lisjak D., Sauerborn Klobučar R., Dragun Z., Bačić N., Klobučar, G. I. V., Gold and silver nanoparticles effects to the earthworm Eisenia fetida - the importance of tissue over soil concentrations, „Drug and Chemical 
Toxicology" 2019, 1-18, https://doi.org/10.1080/014805 45.2019 .1567757

[17] Sánchez-López K. B., De los Santos-Ramos F.J., Gómez-Acata E.S., Luna-Guido M., Navarro-Noya Y. E., Fernández-Luqueño F., Dendooven $\mathrm{L}_{\text {., }} \mathrm{TiO}_{2}$ nanoparticles affect the bacterial community structure and Eisenia fetida (Savigny, 1826) in an arable soil, „PeerJ” 2019, 7, 6939, https://doi.org/10.7717/ peerj.6939.

[18] Miller R. J., Lenihan H. S., Muller E. B., Tseng N., Hanna S. K., Keller A A., Impacts of metal oxide nanoparticles on marine phytoplankton, „Environmental Science \& Technology” 2010, 44, 7329-7334, https://doi.org/10.1021/es100247x.

[19] Haque E., Ward A., Zebrafish as a Model to Evaluate Nanoparticle Toxicity, „Nanomaterials” 2018, 8, 7, https://doi. org/10.3390/nano8070561.

[20] Ivask A., Juganson K., Bondarenko O., Mortimer M., Aruoja V., Kasemets K., Blinova I., Heinlaan M., Slaveykova V., Kahru A., Mechanisms of toxic action of $\mathrm{Ag}, \mathrm{ZnO}$ and $\mathrm{CuO}$ nanoparticles to selected ecotoxicological test organisms and mammalian cells in vitro: A comparative review, "Nanotoxicology" 2014, 8, 57-71, https://doi.org/10.3109/1743539 0.2013 .855831 .

[21] Song G., Ho W., Gao Y., Wang Y., Lin L, Zhang Z., Niu Q., Ma R., Mu L. Wang H., Effects of Cuo nanoparticles on Lemna minor, „Botanical Studies” 2016, 57, 1, https://doi. org/10.1186/s40529-016-0118-x.

[22] Belava V. N., Panyuta O. O., Yakovleva G. M., Pysmenna Y. M., Volkogon M. V., The Effect of Silver and Copper Nanoparticles on the Wheat-Pseudocercosporella herpotrichoides Pathosystem, "Nanoscale Research Letters" 2017, 12, 1, https://doi.org/10.1186/s11671-017-2028-6.

[23] Kelley M., Current K. M., Dissanayake N. M., Obare S. O., Effect of Iron Oxide Nanoparticles and Amoxicillin on Bacterial Growth in the Presence of Dissolved Organic Carbon, „Biomdicines” 2017, 5, 3, https://doi.org/10.3390/ biomedicines 5030055 .

[24] Khan M. S., Qureshi N. A., Jabeen F., Assessment of toxicity in fresh water fish Labeo rohita treated with silver nanoparticles, „Applied Nanoscience” 2017, 7, 167-179, https://doi.org/10.1007/s13204-017-0559-x.

[25] Sukhanova A., Bozrova S., Sokolov P., Berestovoy M., Karaulov A., Nabiev I., Dependence of Nanoparticle Toxicity on Their Physical and Chemical Properties, "Nanoscale research letters" 2018, 13, 1, https://doi.org/10.1186/ s11671-018-2457-x.

[26] Buzea C, Pachec I. I., Robbie K., Nanomaterials and nanoparticles: Sources and toxicity, „Biointerphases” 2007, 2, 4, 17-71, https://doi.org/10.1116/1.2815690.

[27] Christian P., Von der Kammer F., Baalousha M., Hofmann T., Nanoparticles: structure, properties, preparation and behavior in environmental media, „Ecotoxicology” 2008, 17, 326-343, https://doi.org/10.1007/s10646-008-0213-1.

[28] Ge L., Li Q., Wang M., Ouyang J., Li X., Xing M.M.Q., Nanosilver particles in medical applications: synthesis, performance, and toxicity, „International Journal Nanomedicine" 2014, 9, 2399-2407, https://doi.org/10.2147/IJN.S55015.
[20] Zou J., Hannula M., Misra S., Feng H., Labrador R., Aula A. S., Hyttinen J., Pyykkö I., Micro CT visualization of silver nanoparticles in the middle and inner ear of rat and transportation pathway after transtympanic injection, „Journal of Nanobiotechnology" 2015, 13, 1, https://doi. org/10.1186/s12951-015-0065-9.

[30] Farooq M. U., Novosad V., Rozhkova E. A., Wali H., Ali A., Fateh A. A., Neogi P., B., Wang, Z., Gold Nanoparticles-enabled Efficient Dual Delivery of Anticancer Therapeutics to HeLa Cells, „Scientific Reports” 2018, 8, 1, https://doi.org/10.1038/ s41598-018-21331-y.

[31] Sun C., Li Y., Li Z., Su Q., Wang Y., Liu, X., Durable and Washable Antibacterial Copper Nanoparticles Bridged by Surface Grafting Polymer Brushes on Cotton and Polymeric Materials, "Journal of Nanomaterials" 2018, 1-7, https://doi.org/10.1155/2018/6546193.

[32] Ingle A. P., Duran N., Rai M., Bioactivity, mechanism of action, and cytotoxicity of copper-based nanoparticles: A review, „Applied Microbiology and Biotechnology" 2013, 98, 3, 1001-1009, https://doi.org/10.1007/ s00253-013-5422-8.

[33] Jiang J., Pi J., Cai J., The Advancing of Zinc Oxide Nanoparticles for Biomedical Applications, „Bioinorganic Chemistry and Applications" 2018, 1-18, https://doi. org/10.1155/2018/1062562.

[34] Jin S. E., Jin J. E., Hwang W., Hong S. W., Photocatalytic antibacterial application of zinc oxide nanoparticles and self-assembled networks under dual UV irradiation for enhanced disinfection, „International Journal of Nanomedicine" 2018, 14, 1737-1751, https://doi.org/10.2147/IJN. S192277.

[35] Barui A. K., Kotcherlakota R., Patra C. R., Biomedical applications of zinc oxide nanoparticles, "Inorganic Frameworks as Smart Nanomedicines" 2018, 239-278, https://doi.org/10.1016/B978-0-12-813661-4.00006-7.

[36] Mishra P. K., Mishra H., Ekielski A., Talegaonkar S., Vaidya B., Zinc oxide nanoparticles: a promising nanomaterial for biomedical applications, "Drug Discovery Today" 2017, 22, 12, 1825-1834, https://doi.org/10.1016/j. drudis.2017.08.006.

[37] Rabajczyk A., El Yamani N., Dusinska M., The effect of time on the stability of iron oxide nanoparticles in environmental acids, „Water Environment Research” 2017, 89, 5, 416-423, https://doi.org/10.2175/106143016X14609975747685.

[38] Çeşmeli S., Biray Avci C., Application of Titanium Dioxide $\left(\mathrm{TiO}_{2}\right)$ Nanoparticles in Cancer Therapies, "Journal of Drug Targeting" 2019, 1-13, https://doi.org/10.1080/106 1186X.2018.1527338.

[39] Gajbhiye S., Sakharwade S., Silver Nanoparticles in Cosmetics, "Journal of Cosmetics, Dermatological Sciences and Applications" 2016, 6, 48-53, https://doi.org/10.4236/ jcdsa.2016.61007.

[40] Lu P. J., Huang S. C., Chen Y. P., Chiueh L. C., Shih D. Y. C., Analysis of titanium dioxide and zinc oxide nanoparticles in cosmetics, "Journal of Food and Drug Analysis" 2015, 23, 3, 587-594, https://doi.org/10.1016/j.jfda.2015.02.009. 
[41] Lu P. J., Huang S. C., Chen Y. P., Chiueh L. C., Shih D. Y. C., Analysis of titanium dioxide and zinc oxide nanoparticles in cosmetics, "Journal of Food and Drug Analysis" 2015, 23, 3, 587-594, https://doi.org/10.1016/j.jfda.2015.02.009.

[42] Dréno B., Alexis A., Chuberre B., Marinovich M., Safety of titanium dioxide nanoparticles in cosmetics, "Journal of the European Academy of Dermatology and Venereology" 2019, 33, S7, 34-46, https://doi.org/10.1111/jdv.15943.

[43] Hoffmann T., Amaral Peters D., Angioletti B., Bertoli S., Peres Vieira L., Ratto Reiter M.G., Krebs De Souza C., Potentials Nanocomposites in Food Packaging, "Chemical Engineering Transactions" 2019, 75, 253-258.

[44] Huang Y., Mei L., Chen X., Wang Q., Recent Developments in Food Packaging Based on Nanomaterials, "Nanomaterials" 2018, 8, 10, https://doi.org/10.3390/nano8100830.

[45] Peters R. J. B., van Bemmel G., Herrera-Rivera Z., Helsper H. P. F. G., Marvin H. J. P., Weigel S., Tromp P. C., Oomen A. G., Bouwmeester, H., Characterization of Titanium Dioxide Nanoparticles in Food Products: Analytical Methods To Define Nanoparticles, "Journal of Agricultural and Food Chemistry" 2014, 62, 27, 6285-6293, https://doi.org/10.1021/ jf5011885.

[46] Espitia P. J. P., Otoni C. G., Soares N. F. F., Zinc Oxide Nanoparticles for Food Packaging Applications, „Antimicrobial Food Packaging" 2016, 425-431, https://doi.org/10.1016/ B978-0-12-800723-5.00034-6.

[47] Giannossa L. C., Longano D., Ditaranto N., Nitti M. A., Paladini F., Pollini,M., Rai M., Sannino A., Valentini A., Cioffi, N., Metal nanoantimicrobials for textile applications, "Nanotechnology Reviews” 2013, 2, 3, https://doi. org/10.1515/ntrev-2013-0004.

[48] Uddin M. J., Cesano F., Scarano D., Bonino F., Agostini G., Spoto G., Bordiga S., Zecchina, A., Cotton textile fibres coated by Au/TiO2 films: Synthesis, characterization and self cleaning properties, "Journal of Photochemistry and Photobiology A: Chemistry" 2008, 199, 1, 64-72, https://doi. org/10.1016/j.jphotochem.2008.05.004.

[49] El-Nahhal I. M., Zourab S. M., Kodeh F. S., Selmane M., Genois I., Babonneau F., Nanostructured copper oxide-cotton fibers: synthesis, characterization, and applications, "International Nano Letters" 2012, 2, https://doi. org/10.1186/2228-5326-2-14.

[50] Verbič A., Gorjanc M., Simončič B., Zinc Oxide for Functional Textile Coatings: Recent Advances, „Coatings" 2019, 9 , 9, https://doi.org/10.3390/coatings9090550.

[51] Guerra F., Attia M., Whitehead D., Alexis F., Nanotechnology for Environmental Remediation: Materials and Applications, "Molecules" 2018, 23, 7, https://doi.org/10.3390/ molecules23071760.

[52] Amde M., Liu, J. F., Tan Z. Q., Bekana D., Ionic liquid-based zinc oxide nanofluid for vortex assisted liquid liquid microextraction of inorganic mercury in environmental waters prior to cold vapor atomic fluorescence spectroscopic detection, Talanta 149, 2016, 341-346, https://doi. org/10.1016/j.talanta.2015.12.004.

[53] Gehrke I., Geiser A., Somborn-Schulz A., Innovations in na- notechnology for water treatment, Nanotechnology, Science and Applications 1, 2015, https://doi.org/10.2147/NSA. S43773.

[54] Beek W. J. E., Wienk M. M., Janseen R. A. J., Efficient Hybrid Solar Cells from Zinc Oxide Nanoparticles and a Conjugated Polymer, Advanced Mater 16, 12, 2004, pp. 10091013, https://doi.org/10.1002/adma.200306659.

[55] Shweta, Pal K., Thapa K. B., Synthesis and characterization of ZnO nano-particles for solar cell application by the cost effective co-precipitation method without any surfactants, AIP Conference Proceedings 2142, 1, 2019, https:// doi.org/10.1063/1.5122336.

[56] Yuan Z., Low-temperature growth of well-aligned ZnO nanowire arrays by chemical bath deposition for hybrid solar cell application, "Journal of Material Science: Material in Electronics" 2014, 25, 5, 2248-2252, https://doi. org/10.1007/s10854-014-1866-6.

[57] Yuan Z., Synthesis of ZnO nanocrystal by thermal decomposition for inverted polymer solar cell application, „Journal of Material Science: Material in Electronics" 2015, 26, 3, 1776-1779, https://doi.org/10.1007/s1 0854-014-2607-6.

[58] Chelladurai K., Rajamanickam M., Environmentally Benign Neem Biodiesel Synthesis Using Nano-Zn-Mg-Al Hydrotalcite as Solid Base Catalysts, "Journal of Catalysts" 2014, 1-6, https://doi.org/10.1155/2014/326575.

[59] Kumar R., Al-Dossary O., Kumar G., Umar A., Zinc Oxide Nanostructures for $\mathrm{NO}_{2}$ Gas-Sensor Applications: A Review, „Nano-Micro Letters” 2014, 7, 2, 97-120, https://doi. org/10.1007/s40820-014-0023-3.

[60] Wang Z. L., Zinc oxide nanostructures: growth, properties and applications, "Journal of Physics. Condensed Matter" 2004, 16, 25, 829-858, https://doi. org/10.1088/0953-8984/16/25/R01.

[61] Moballegh A, Shahverdi H. R, Aghababazadeh R., Mirhabibi A., ZnO nanoparticles obtained by mechanochemical technique and the optical properties, „Surface Science" 2007, 601,13, 2850-2854, https://doi.org/10.1016/j. susc.2006.12.012

[62] Bacaksiz E., Parlak M., Tomakin M., Özçelik A., Karakiz M., Altunbaş M., The effects of zinc nitrate, zinc acetate and zinc chloride precursors on investigation of structural and optical properties of $\mathrm{ZnO}$ thin films, "Journal of Alloys Compounds" 2008, 466, 1-2, 447-450, https://doi.or$\mathrm{g} / 10.1016 / j$.jallcom.2007.11.061.

[63] Segets D., Gradl J., Taylor R. K., Vassilev V., Peukert W., Analysis of Optical Absorbance Spectra for the Determination of ZnO Nanoparticle Size Distribution, Solubility and Surface Energy, "ACS Nano” 2009, 3, 7, 1703-1710, https://doi.org/10.1021/nn900223b.

[64] Feng L., Liu A., Liu M., Ma Y., Wei J., Man B., Fabrication and characterization of tetrapod-like $\mathrm{ZnO}$ nanostructures prepared by catalyst-free thermal evaporation, „Materials Characterization" 2010, 61, 128-133, https://doi.org/10.1016/j.matchar.2009.10.011.

[65] Huang C. L., Hsiao I. L., Lin H. C., Wang C. F., Huang Y. J., Chuang C. Y., Silver nanoparticles affect on gene expres- 
sion of inflammatory and neurodegenerative responses in mouse brain neural cells, "Environmental Research" 2015, 136, 253-263, https://doi.org/10.1016/j. envres.2014.11.006.

[66] Gupta R., Xie H., Nanoparticles in Daily Life: Applications, Toxicity and Regulations, "Journal of Environmental Pathology, Toxicology and Oncology" 2018, 37, 3, 209-230, https://doi.org/10.1615/ JEnvironPatholToxicolOncol.2018026009.

[67] Taylor D. A., Dust in the wind, „Environmental Health Perspectives" 2002, 110, 2, A80-A87, https://doi. org/10.1289/ehp.110-a80.

[68] Jeevanandam, J., Barhoum A., Chan S., Dufresne A., Danquah M., Review on nanoparticles and nanostructured materials: History, sources, toxicity and regulations, „Beilstein Journal of Nanotechnology" 2018, 9, 1, 1050-1074, https://doi.org/10.3762/bjnano.9.98.

[69] Delay M., Frimmel F. H., Nanoparticles in aquatic systems, „Analytical and Bioanalytical Chemistry” 2012, 402, 583-592, https://doi.org/10.1007/s00216-011-5443-z.

[70] Contini C., Schneemilch M., Gaisford S., Quirke N., Nanoparticle-membrane interactions, „Journal of Experimental Nanoscience" 2018, 13, 1, 62-81, https://doi.org/10.1080 $/ 17458080.2017 .1413253$.

[71] Manke A., Wang L., Rojanasakul Y., Mechanisms of Nanoparticle-Induced Oxidative Stress and Toxicity, „Biomed Research International" 2013, 942916, https://doi. org/10.1155/2013/942916.

[72] Dayem A. A., Hossain M. K., Lee S. B., Kim K., Saha S. K., Yang G. M., Choi H. Y., Cho S.G., The Role of Reactive Oxygen Species (ROS) in the Biological Activities of Metallic Nanoparticles, „International Journal of Molecular Sciences" 2017, 18, 1, https://doi.org/10.3390/ijms18010120

[73] Siddiqi K. S., ur Rahman A., Tajuddin, Husen A., Properties of Zinc Oxide Nanoparticles and Their Activity Against Microbes, "Nanoscale Research Letters" 2018, 13, 1, https://doi.org/10.1186/s11671-018-2532-3.

[74] Wang L., Hu Ch., Shao L., The antimicrobial activity of nanoparticles: present situation and prospects for the future, "International Journal of Nanomedicine" 2017, 12, 1227-1249, https://doi.org/10.2147/IJN.S121956.

[75] Sirelkhatim A., Mahmud S., Seeni A., Kaus N. H. M., Ann L. Ch., Bakhori S. K. M., Hasan H., Mohamad D., Review on Zinc Oxide Nanoparticles: Antibacterial Activity and Toxicity Mechanism, „Nanomicro Letters” 2015, 7, 3, 219-242, https://doi.org/10.1007/s40820-015-0040-x.

[76] Yang E.J., Kim S., Kim J.S., Choi I.H., Inflammasome formation and $I L-1 \beta$ release by human blood monocytes in response to silver nanoparticles, "Biomaterials" 2012, 33, 6858-6867, https://doi.org/10.1016/j. biomaterials.2012.06.016.

[77] Zhang T., Wang L., Chen Q., Chen Ch., Cytotoxic Potential of Silver Nanoparticles, "Yonsei Medical Journal” 2014, 55, 2 , 283-291, https://doi.org/10.3349/ymj.2014.55.2.283.

[78] Adams L. K., Lyon D. Y., Alvarez P. J. J. Comparative ecotoxicity of nanoscale $\mathrm{TiO}_{2}, \mathrm{SiO}_{2}$, and $\mathrm{ZnO}$ water suspen- sions, „Water Research” 2006, 40, 3527-3532, https://doi. org/10.1016/j.watres.2006.08.004.

[79] Fiedot M., Maliszewska I., Rac-Rumijowska O., Suchorska-Woźniak P., Lewińska A., Teterycz H., The Relationship between the Mechanism of Zinc Oxide Crystallization and Its Antimicrobial Properties for the Surface Modification of Surgical Meshes, "Materials (Basel)" 2017, 10, 4, https://doi.org/10.3390/ma10040353.

[80] Azam A., Ahmed A. S., Oves M., Khan M. S., Habib S. S., Memic A., Antimicrobial activity of metal oxide nanoparticles against Gram-positive and Gram-negative bacteria: a comparative study, ,International Journal of Nanomedicine" 2012, 7, https://doi.org/10.2147/IJN.S35347.

[81] Niño-Martínez N., Orozco M. S. S., Martínez-Castañón G. A., Méndez F. T., Ruiz F., Molecular Mechanisms of Bacterial Resistance to Metal and Metal Oxide Nanoparticles, „International Journal of Molecular Sciences" 2019, 20, 11, https://doi.org/10.3390/ijms20112808.

[82] Ramesh C., Mohan Kumar K. T., Senthil M., Ragunathan V., Antibacterial activity of $\mathrm{Cr}_{2} \mathrm{O}_{3}$ nanoparticles against E.coli; Reduction of chromate ions by Arachis hypogaea leaves, „Archives of Applied Science Research" 2012, 4, 4, 1894-190.

[83] Bind V., Kumar A., Current issue on nanoparticle toxicity to aquatic organism, "MOJ Toxicology" 2019, 5, 2, 66-67.

[84] Pramod K. S., Vijayasundaram V., Krishnakumar N., Palaniappan PI.Rm., The effect of titanium dioxide exposure on the thermal properties of Zebrafish (Danio rerio) bones, "Journal of Thermal Analysis and Calorimetry" 2012, 108, 1, 133-139, https://doi.org/10.1007/s10973-011-1774-4.

[85] Zhang J., Guo W., Li Q., Wang Z., Liu S., The effects and the potential mechanism of environmental transformation of metal nanoparticles on their toxicity in organisms, „Environmental Science: Nano" 2018, 5, 11, 2482-2499, https://doi.org/10.1039/C8EN00688A.

[86] Lacave J. M., Vicario-Parés U., Bilbao E., Gilliland D., Mura F., Dini L., Cajaraville M. P., Orbea A., Waterborne exposure of adult zebrafish to silver nanoparticles and to ionic silver results in differential silver accumulation and effects at cellular and molecular levels, "Science of The Total Environment" 2018, 642, 1209-1220, https://doi.org/10.1016/j. scitotenv.2018.06.128.

[87] Griffitt R. J., Luo J., Gao J., Bonzongo J. C., Barber D. S., Effects of particle composition anad species on toxicity of metallic nanomaterials in aquatic organisms, „Environmental Toxicology and Chemistry" 2008, 27, 9, https://doi. org/10.1897/08-002.1.

[88] Lekamge S., Miranda A. F., Abraham A., Li V., Shukla R., Bansal V., Nugegoda D., The Toxicity of Silver Nanoparticles (AgNPs) to Three Freshwater Invertebrates With Different Life Strategies: Hydra vulgaris, Daphnia carinata, and Paratya australiensis, „Frontiers in Environmental Science” 2018, 6, 1-13, https://doi.org/10.3389/fenvs.2018.00152.

[89] Zhang Z., Yang X., Shen M., Yin Y., Liu J., Sunlight-driven reduction of silver ion to silver nanoparticleby organic matter mitigates the acute toxicity of silver to Daphnia magna, 
„Journal of Environmental Sciences" 2015, 35, 62-68, https://doi.org/10.1016/j.jes.2015.03.007.

[90] Gosteva I., Morgalev Y., Morgaleva T., Morgalev S., Effect of $\mathrm{Al}_{2} \mathrm{O}_{3}$ and $\mathrm{TiO}_{2}$ nanoparticles on aquatic organisms, IOP Conference Series: Materials Science and Engineering 98, 2015, https://doi.org/10.1088/1757-899X/98/1/012007.

[91] Borase H. P., Muley A. B., Patil S. V., Singhal R. S., Nano-eco toxicity study of gold nanoparticles on less explored aquatic organism Moina macrocopa: enzymatic biomarkers and bioaccumulation perspective, "Environmental Toxicology and Pharmacology" 2019, 68, 4-12, https://doi.org/10.1016/j.etap.2019.02.013.

[92] Dabrunz A., Duester L., Prasse C., Seitz F., Rosenfeldt R., Schilde C., Schaumann G.E., Schulz R., Biological Surface Coating and Molting Inhibition as Mechanisms of $\mathrm{TiO}_{2} \mathrm{Na}$ noparticle Toxicity in Daphnia magna, PLoS ONE 6, 2011, https://doi.org/10.1371/journal.pone.0020112.

[93] Aruoja V., Pokhrel S., Sihtmäe M., Mortimer M., Mädler L., Kahru A., Toxicity of 12 metal-based nanoparticles to algae, bacteria and protozoa, "Environmental Science Nano” 2015, 6, https://doi.org/10.1039/C5EN00057B.

[94] Heinlaan M., Ivask A., Blinova I., Dubourguier H.C., Kahru A., Toxicity of nanosized and bulk $\mathrm{ZnO}, \mathrm{CuO}$ and $\mathrm{TiO}_{2}$ to bacteria Vibrio fischeri and crustaceans Daphnia magna and Thamnocephalus platyurus, "Chemosphere" 2008, 71, 7, 1308-1316, https://doi.org/10.1016/j. chemosphere.2007.11.047.

[95] Aruoja V., Dubourguier H.C., Kasemets K., Kahru A., Toxicity of nanoparticles of $\mathrm{CuO}, \mathrm{ZnO}$ and $\mathrm{TiO}_{2}$ to microalgae Pseudokirchneriella subcapitata, "Science of the Total Environment" 2009, 407, 4, https://doi.org/10.1016/j. scitotenv.2008.10.053.

[96] Sovová T., Kocí V., Kochánková L., Ecotoxicity of nano and bulk forms of metal oxides, Conference: 1 st NANOCON International Conference, At: Rožnov p. Radhoštěm, Czech Republic, 2009.

[97] Mortimer M., Kasemets K., Kahru A., Toxicity of ZnO and CuO nanoparticles to ciliated protozoa Tetrahymena thermophila, "Toxicology" 2009, 269, 2-3, 182-189, https://doi. org/10.1016/j.tox.2009.07.007.

[98] Kovrižnych J. S., Sotníková R., Zeljenková D., Rollerová E., Szabová E., Long-term (30 days) toxicity of NiO nanoparticles for adult zebrafish Danio rerio, "Interdisciplinary Toxicology" 2014, 7, 1, 23-26, https://doi.org/10.2478/ intox-2014-0004.

[99] Lopes S., Ribeiro F., Wojnarowicz J., Łojkowski W., Jurkschat K., Crossley A., Soares A.M.V.M., Loureiro S., Zinc oxide nanoparticles toxicity to Daphnia magna: size-dependent effects and dissolution, "Environmental Toxicology and Chemistry” 2014, 33, 190-198, https://doi.org/10.1002/etc.2413.

[100] Hartmann N.B., Von der Kammer F., Hofmann T., Baalousha M., Ottofuelling S., Baun A. Algal testing of titanium dioxide nanoparticles--testing considerations, inhibitory effects and modification of cadmium bioavailability, "Toxicology" 2010, 269, 2-3, 190-197, https://doi. org/10.1016/j.tox.2009.08.008.
[10] Dalai S., Pakrashi S., Chandrasekaran N., Mukherjee A., Acute Toxicity of $\mathrm{TiO}_{2}$ Nanoparticles to Ceriodaphnia dubia under Visible Light and Dark Conditions in a Freshwater System, PLoS One 8, 4, 2013, https://doi.org/10.1371/ journal.pone.0062970.

[102] Artells E., Issartel J., Auffan M., Borschneck D., Thill A., Tella M., Brousset L., Rose J., Bottero J.Y., Thiéry A., Exposure to Cerium Dioxide Nanoparticles Differently Affect Swimming Performance and Survival in Two Daphnid Species, PLoS One 8, 8, 2013, https://doi.org/10.1371/journal.pone.0071260.

[103] Pelletier D. A., Suresh A. K., Holton G. A., McKeown C. K., Wang W., Gu B., Mortensen N. P., Allison D. P., Joy D. C., Allison M. R., Brown S. D., Phelps T. J., Doktycz, M. J., Effects of Engineered Cerium Oxide Nanoparticles on Bacterial Growth and Viability, „Applied and Environmental Microbiology" 2010, 76, 24, 7981-7989, https://doi.org/10.1128/AEM.00650-10.

[104] Thill A., Zeyons O., Spalla O., Chauvat F., Rose J., Auffan M., Flank A. M., Cytotoxicity of $\mathrm{CeO}_{2}$ nanoparticles for Escherichia coli. physico-chemical insight of the cytotoxicity mechanism, „Environmental Science \& Technology” 2006, 40, 6151-6156, https://doi.org/10.1021/es060999b.

[105] Rodea-Palomares I.,Boltes K., Fernández-Piñas F., Leganés F., García-Calvo E., Santiago J., Rosal R., Physicochemical Characterization and Ecotoxicological Assessment of $\mathrm{CeO}_{2}$ Nanoparticles Using Two Aquatic Microorganisms, "Toxicological Sciences" 2011, 119, 1, 135-145, https:// doi.org/10.1093/toxsci/kfq311.

[106] Rogers N. J., Franklin N. M., Apte S. A., Batley G. E., Angel B. M., Lead J. R., Baalousha M., Physico-chemical behaviour and algal toxicity of nanoparticulate $\mathrm{CeO}_{2}$ in freshwater, „Environmental Chemistry" 2010, 7, 50-60, https://doi. org/10.1071/EN09123.

[107] Van Hoecke K., Quik J. T., Mankiewicz-Boczek J., De Schamphelaere K. A., Elsaesser A., Van der Meeren P., Barnes C., McKerr G., Howard C. V., Van de Meent D., Rydzyński K., Dawson K. A., Salvati A., Lesniak A., Lynch I., Silversmit G., De Samber B., Vincze L., Janssen C.R., Fate and effects of $\mathrm{CeO}_{2}$ nanoparticles in aquatic ecotoxicity tests, "Environmental Science \& Technology” 2009, 43, 12, 4537-4546, https://doi.org/10.1021/es9002444.

[108] Zhang H., He X., Zhang Z., Zhang P., Li Y., Ma Y., Kuang Y., Zhao Y., Chai Z., Nano- $\mathrm{CeO}_{2}$ exhibits adverse effects at environmental relevant concentrations, "Environmental Science \& Technology" 2011, 45, 8, 3725-3730, https://doi.org/10.1021/es103309n.

[109] Garaud M., Auffan M., Devin S., Felten V., Pagnout Ch., Pain-Devin S., Proux O., Rodius F., Sohm B., Giamberini L., Integrated assessment of ceria nanoparticle impacts on the freshwater bivalve Dreissena polymorpha, "Nanotoxicology" 2016, 10, 7, 935-944, https://doi.org/10.3109/17 435390.2016.1146363.

[110] Conway J. R., Hanna S. K., Lenihan H. S., Keller A. A., Effects and implications of trophic transfer and accumulation of $\mathrm{CeO}_{2}$ nanoparticles in a marine mussel, "Environmental Science \& Technology" 2014, 48, 1517-1524, https://doi.org/10.1021/es404549u. 
[111] Johnston B. D., Scown T. M., Moger J., Cumberland S. A., Baalousha M., Linge K., vanAerle R., Jarvis K., Lead J. R., Tyler C. R. Bioavailability of nanoscale metal oxides $\mathrm{TiO}_{2}$, $\mathrm{CeO}_{2}$, and $\mathrm{ZnO}$ to fish, "Environmental Science \& Technology" 2010, 44, 1144-1151, https://doi.org/10.1021/ es901971a.

[112] Stanley J. K., Coleman J. G., Weiss C. A. Jr, Steevens J. A., Sediment toxicity and bioaccumulation of nano and micron-sized aluminum oxide, „Environmental Toxicology and Chemistry" 2010, 29, 2, 422-429, https://doi. org/10.1002/etc.52.

[113] Minaeian S., Shahverdi A. R., Nohi A. S., Shahverdi H. R., Extracellular biosynthesis of silver nanoparticles by some bacteria, "JSIAU” 2008, 17, 66, 1-4.

[114] Das V. L., Thomas R., Varghese R. T., Soniya E. V., Mathew J., Radhakrishnan E. K., Extracellular synthesis of silver nanoparticles by the Bacillus strain CS 11 isolated from industrialized area, „3 Biotech” 2013, 4, 2, 121-126, https://doi.org/10.1007/s13205-013-0130-8.

[115] Joerger R., Klaus T., Granqvist C.G., Biologically produced silver-carbon composite materials for optical-
Iy functional thin film coatings, "Advanced Materials" 2010, 12, 407-409, https://doi.org/10.1002/(SICI)1521-4095(200003)12:6<407::AID-ADMA407>3.0.CO;2-0.

[116] Nair B., Pradeep T., Coalescence of nano-clusters and formation of submicron crystallites assisted by Lactobacillus strains, "Cryst Growth Design” 2002, 2, 293-298, https://doi.org/10.1021/cg0255164.

[117] Shahverdi A. R., Minaeian S., Shahverdi H. R., Jamalifar H., Nohi A. A., Rapid synthesis of silver nanoparticles using culture supernatants of Enterobacteria: a novel biological approach, „Process Biochemistry” 2007, 42, 919-923, https://doi.org/10.1016/j.procbio.2007.02.005.

[118] Sinha S., Pan I., Chanda P., Sen S. K., Nanoparticles fabrication using ambient biological resources, „Journal of Applied Bioscienced 2009, 19, 1113-1130.

[119] Rather M. A., Bhat I. A., Sharma N., Sharma R., Molecular and Cellular Toxicology of Nanomaterials with Related to Aquatic Organisms, „Advances in Experimental Medicine and Biology" 2018, 1048, 263-284, https://doi. org/10.1007/978-3-319-72041-8_16.
ILONA TOMCZYK-WYDRYCH, M.SC. - she graduated from the Jan Kochanowski University in Kielce in the field of Environmental Protection with a specialization in environmental monitoring and environmental management. Employee of State Water Holding Polish Waters. Scientific interests focus on the migration of metal and metal oxides nanoparticles in the aquatic environment and their interaction with compounds present in surface waters.

ANNA RABAJCZYK, D.SC. - Associate Professor at the Scientific and Research Centre for Fire Protection - National Research Institute. She graduated from WSP in Kielce. Doctorate in chemistry at the University of Opole. Habilitation in environmental engineering at the Wrocław University of Technology. Environmental auditor. She has extensive scientific and didactic experience, and deals with issues to environmental engineering, nanotechnology, biotechnology as well as chemical transformation and environmental threats. She is an expert in national and international institutions (including NCBR, EC, The European Education and Training Expert Panel). She completed numerous both domestic and foreign internships and scholarships, she was a member in many scientific and organizational committees of both domestic and foreign conferences.
MGR ILONA TOMCZYK-WYDRYCH - Absolwentka Uniwersytetu Jana Kochanowskiego w Kielcach, kierunek ochrona środowiska o specjalności monitoring środowiska oraz zarządzanie środowiskowe. Pracownik Państwowego Gospodarstwa Wodnego Wody Polskie. Zainteresowania naukowe koncentrują się na migracji nanocząstek metali i tlenków metali w środowisku wodnym oraz ich interakcji z innymi związkami obecnymi w wodach powierzchniowych.

DR HAB. ANNARABAJCZYK - profesor Centrum Naukowo-Badawczego Ochrony Przeciwpożarowej im. Józefa Tuliszkowskiego - Państwowego Instytutu Badawczego. Absolwent WSP w Kielcach, kierunek chemia. Doktorat z chemii na Uniwersytecie Opolskim. Habilitacja z inżynierii środowiska na Politechnice Wrocławskiej. Audytor środowiskowy. Posiada bogate doświadczenie naukowe i dydaktyczne. Zajmuje się zagadnieniami inżynierii środowiska, nanotechnologii, biotechnologii oraz transformacji chemicznej i zagrożeń środowiskowych. Pełni rolę eksperta w krajowych i międzynarodowych instytucjach (m.in. NCBR, EC, The European Education and Training Expert Panel). Odbyła liczne staże i stypendia krajowe i zagraniczne, była członkiem w wielu komitetach naukowych i organizacyjnych konferencji zarówno krajowych, jak i zagranicznych. 